\title{
Jaka rodzina? Jakie dzieci? Jakie społeczeństwo? Refleksje socjologa nad społecznymi skutkami przemian rodziny
}

Rodzina „od zawsze” stanowiła trwały i podstawowy element większej społecznej struktury. Dzięki niej rodziły się kolejne pokolenia, które skrzętnie pomnażały materialny i kulturowy dorobek rodu, społeczeństwa (narodu, państwa), podporządkowując się potrzebom tychże społeczności (np. podniesienia splendoru rodu, jego wzbogacenia, realizacji powiązań politycznych, wzrostu demograficznego i ekonomicznego potencjału, itp.) ${ }^{1}$. Jedno-

1 Dane na ten temat można znaleźć $\mathrm{z}$ bogatej literaturze opisującej życie rodzin w dawnych wiekach, a ściślej mówiąc - w społeczeństwach przedindustrialnych oraz w kulturach tradycyjnych. Zob. m.in. Historia życia prywatnego, ed. Ph. Ariès, G. Duby, tłum. K. Arustowicz, M. Rostworowska, red. wyd. pol. A. Łoś, t. 1-5, Wrocław-Warszawa-Kraków 1999; M. Barański, Rodzina od czasów najdawniejszych do końca XVIII wieku, w: Przemiany rodziny polskiej, red. J. Komorowska, Warszawa 1975, s. 23-51; M. Bogucka, Gorsza płeć. Kobieta $w$ dziejach Europy od antyku po wiek XXI, Warszawa 2006; J.-L. Flandrin, Historia rodziny, tłum. A. Kuryś, Warszawa 1998; J. Iluk, Chrześcijańskie małżeństwo i rodzina w rzymskiej starożytności, w: W. Pałubicki, J. Iluk, Małżeństwo i rodzina $w$ dawnym judaizmie i starożytnym chrześcijaństwie, Gdańsk 1995, s. 153-289; Z. Jabłonowska, Rodzina w XIX i na początku XX wieku, w: Przemiany rodziny polskiej, dz. cyt., s. 52-71; M. Marody, A. Giza-Poleszczuk, 
cześnie członkowie rodzin czerpali własne korzyści w postaci: zrodzenia prawowitego dziedzica majątku i nazwiska, zabezpieczenia dzieciom ścisłego i dziedzicznego po ojcu statusu społecznego i klasowego, zyskania prawa do opieki nad dziećmi, ale i innymi członkami rodziny, zwłaszcza w razie śmierci męża i ojca rodziny, uzyskania przez małżonków dodatkowego źródła zabezpieczenia ekonomicznego (np. dla żony w postaci utrzymywania jej przez męża, dla męża - dysponowania posagiem żony), wreszcie pozyskania wyższego statusu społecznego w wyniku dowiedzenia wysokiej (mierzonej ówczesnymi standardami) atrakcyjności na rynku matrymonialnym ${ }^{2}$. W rodzinie zaspokajane były również podstawowe potrzeby biologiczne i psychiczne jednostek, co - w świetle współczesnych badań psychologicznych - przekładało się na dobro społeczne w postaci optymalnego poziomu zdrowia psychicznego całego społeczeństwa ${ }^{3}$.

Współczesne interdyscyplinarne badania nad znaczeniem rodziny dla jednostki i społeczeństwa pozwalają stwierdzić, iż rodzina jest niezastępowalnym środowiskiem, gdyż: 1) umożliwia zaspokojenie podstawowych potrzeb psychicznych dziecka (miłości, przywiązania, bezpieczeństwa), dzięki czemu może ono rozwinąć dojrzałą, zdrową osobowość oraz budować pozytywne społeczne kontakty $\mathrm{z}$ innymi ludźmi (rodzina jako środowisko rozwoju osobowościowego); 2) dostarcza wsparcia psychicznego i pomocy osobom dorosłym; zatem chroni przed egoizmem oraz poczuciem chronicznego osamotnienia (rodzina jako środowisko solidarności międzypokoleniowej, chroniące przed utratą sensu życia); 3) ojciec i matka są wzorami

Przemiany więzi społecznych. Zarys teorii zmiany społecznej, Warszawa 2004; M. Żyromski, Rodzina jako podstawowa mikrostruktura społeczna w średniowiecznej Polsce, „Roczniki Socjologii Rodziny" 10 (1998), s. 145-157.

2 Pisałam o tym w artykule: E. Budzyńska, Koniec rodziny, jaka znamy?, w: Problemy wspótczesnej demokracji i moralności, red. J. Kopka, G. Matuszczak, Łódź 2010, s. 281-303; Por. F. Adamski, Rodzina. Wymiar społeczno-kulturowy, Kraków 2002; J. Rostowski, Wspótczesne przemiany rozumienia związku małżeńskiego, w: Psychologia rodziny. Małżeństwo i rodzina wobec wspótczesnych wyzwań, red. T. Rostowska, Warszawa 2009, s. 15-46.

3 Na ten aspekt funkcjonowania rodziny zwróciła uwagę Maria Ziemska, przypisując psychohigienicznej funkcji rodziny zapewnienie członkom rodziny poczucia bezpieczeństwa, stabilizacji, zaspokojenie potrzeb emocjonalnych, co stanowi gwarancję ich dojrzałości emocjonalnej i równowagi psychicznej. W ten sposób funkcja ta przyczynia się do poprawy zdrowia psychicznego całego społeczeństwa, a to z kolei wpływa na poprawę jego funkcjonalności w różnych dziedzinach społecznego życia (np. ekonomicznej). Por. M. Ziemska, Wpływ przemian funkcji rodziny na socjalizację dzieci, w: Rodzina i dziecko, red. M. Ziemska, Warszawa 1979, s. 233-235. 
do naśladowania zachowań charakterystycznych dla własnej płci, zaś relacje zachodzące pomiędzy nimi i obserwowane przez dziecko stanowią wzorzec dla jego późniejszych odniesień wobec płci przeciwnej; 4) życie w rodzinie pełnej, w obecności obydwojga rodziców, umożliwia „wyuczenie się" pełnienia podstawowych ról społecznych: ojca, męża, matki, żony (rodzina jako miejsce tworzenia tożsamości płciowej i wzorów międzypłciowych odniesień); 5) doświadczenie na sobie miłości ojcowskiej i macierzyńskiej umożliwia w przyszłości obdarzanie taką miłością własnych dzieci (rodzina jako środowisko tworzenia międzygeneracyjnych więzi); 6) wydając na świat potomstwo, rodzina gwarantuje zastępowalność pokoleń, a tym samym biologiczne trwanie społeczeństwa (narodu) mimo biegu historii (rodzina jako źródło kapitału demograficznego); 7) rodzina przekazuje swoim dzieciom język, religię, obyczaje i zwyczaje kultury, wzory codziennych i odświętnych zachowań, system wartości i norm moralno-społecznych 8) dzięki zaspokajaniu potrzeb psychicznych jej członków przyczynia się do wzrostu poziomu zdrowia psychicznego społeczeństwa, stanowiąc bufor dla powstawania społecznych kryzysów (rodzina jako źródło kapitału społecznego); 9) potomstwo zrodzone i wychowywane przez rodzinę to przyszli pracownicy i podatnicy. Rodzina zatem stanowi podstawowy filar systemu ekonomicznego państwa (rodzina jako źródło kapitału ekonomicznego).

Waga wypełnianych przez rodzinę zadań została dostrzeżona i opisana przez socjologów skupionych na wymiarze strukturalno-funkcjonalnym tej grupy społecznej, co znalazło odzwierciedlenie w tworzonych typologiach funkcji rodziny - bardziej akcentujących aspekt instytucjonalny bądź bardziej skupionych na aspekcie wewnątrzgrupowym wypełniania przez rodzinę funkcji ${ }^{4}$ oraz w koncepcjach struktury rodziny i jej wymiarów, do

4 Do najbardziej znanych należą typologie Franciszka Adamskiego (podział na odrębne funkcje instytucjonalne oraz osobowe), Zbigniewa Tyszki (wyodrębnienie jedenastu szczegółowych funkcji, wbudowanych w szersze kategorie, które stały się podstawą do utworzenia typologii rodzinnych więzi) oraz Marii Ziemskiej (ujęcie poszczególnych funkcji dwuaspektowo - jako zaspokajających z jednej strony potrzeby społeczeństwa, czyli makrostruktury, a z drugiej - potrzeby członków rodziny, czyli mikrostruktury). Zob. F. Adamski, Rodzina. Wymiar społeczno-kulturowy, dz. cyt.; Z. Tyszka, Struktura i funkcje rodziny oraz świadomość rodzinna, w: Podstawowe pojęcia i zagadnienia socjologii rodziny, red. Z. Tyszka, A. Wachowiak, Poznań 1997, s. 43-60; M. Ziemska, Wpływ przemian funkcji rodziny na socjalizacje dzieci, dz. cyt., s. 227-254. Według autorki niniejszego opracowania pośród licznych funkcji rodziny należałoby dostrzec jeszcze jedną - niezwykle ważną zarówno dla jednostki, jak i dla społeczeństwa, a zwłaszcza dla przyszłych rodzin, które będą tworzone przez kolejne młode 
których zaliczono np. formy instytucjonalne tworzące małżeństwo i rodzinę, wzory regulujące współżycie wewnątrz rodziny oraz wyznaczające hierarchię władzy i autorytetu, układ wzajemnie powiązanych rodzinnych ról społecznych, stosunki zachodzące pomiędzy rodzicami i dziećmi, struktury dziedziczenia majątku, władzy lub nazwiska, a także cykle życia małżeńsko-rodzinnego ${ }^{5}$. Oba aspekty funkcjonowania rodziny - instytucjonalno-grupowy oraz funkcjonalno-strukturalny - odnajdziemy w klasycznych socjologicznych definicjach rodziny, podawanych przez Leona Dyczewskiego lub Franciszka Adamskiego ${ }^{6}$ oraz w definicji podanej przez Lubę Sołomę zmodyfikowanej przez Ewę Budzyńską - zob. tabela 1.

Tabela 1. Przykład klasycznej definicji rodziny

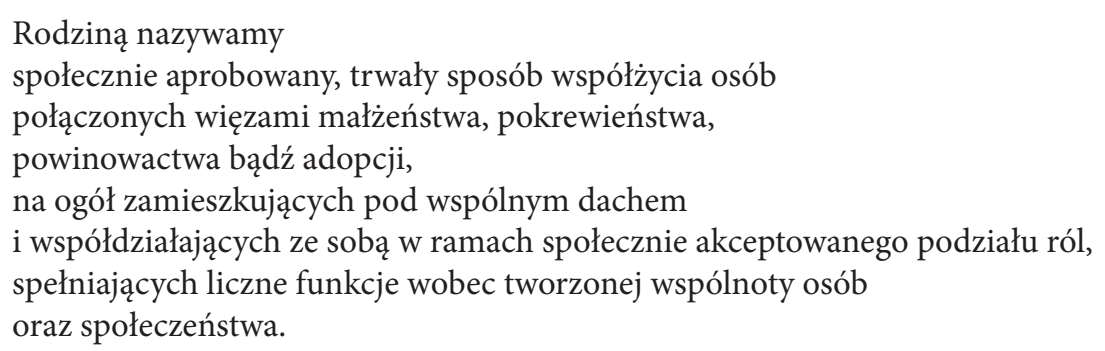

Źródło: opracowanie własne na podstawie: L. Sołoma, Socjologia, Olsztyn 1998, s. 123.

pokolenia. Jest nią więziotwórcza funkcja rodziny, odpowiadająca za kształtowanie umiejętności nawiązywania przez człowieka trwałych emocjonalnych więzi z innymi osobami, przynoszących satysfakcję w całym późniejszym życiu zarówno jednostce, jak i partnerom interakcji. Umiejętność owa kształtuje się u człowieka we wczesnych stadiach jego rozwoju wyłącznie jako efekt aktywnego uczestnictwa w interakcjach $\mathrm{z}$ rodzicami (zwłaszcza z matką jako osobą znaczącą w pierwszych trzech latach życia dziecka). Por. E. Budzyńska, Małe dzieci - mały kłopot? Więziotwórcze funkcje rodziny, w: Więzi międzypokoleniowe w rodzinie i w kulturze, red. W. Świątkiewicz, Katowice 2012, s. 93-135; E. Budzyńska, Międzypokoleniowe więzi w rodzinie. Studium socjologiczne rodzin polskich i słowackich, Katowice 2018, s. 70-71.

5 Zbigniew Tyszka nieco inaczej opisał strukturę rodziny, wyróżniając w niej cztery aspekty: psychologiczny - uwzględniający układ więzi emocjonalnych, społeczny - odnoszący się do pozycji społecznych i struktury władzy, kulturowy - ujmujący zasady regulujące życie rodzinne, normy i wzory wewnątrzrodzinnych ról społecznych i demograficzny określający liczbę członków rodziny, w tym dzieci. Por. Z. Tyszka, A. Wachowiak, Struktura i funkcje rodziny oraz świadomość rodzinna, dz. cyt., s. 44-46; F. Adamski, Rodzina. Wymiar społeczno-kulturowy, dz. cyt., s. 34 .

6 Por. L. Dyczewski, Rodzina. Społeczeństwo. Państwo, Lublin 1994; F. Adamski, Rodzina. Wymiar społeczno-kulturowy, dz. cyt.

7 Por. L. Sołoma, Socjologia, Olsztyn 1998, s. 123. 
$\mathrm{W}$ związku z tak dużym realnym znaczeniem rodziny dla społecznych struktur, ich trwania i rozwoju ta szczególna w swoim rodzaju grupa/instytucja społeczna, jaką jest rodzina, przez teoretyków i badaczy z różnych dyscyplin naukowych została uznana za najtrwalszy i najstarszy element organizacji społecznej, posiadający charakter uniwersalny i występujący we wszystkich epokach, społeczeństwach i kulturach ${ }^{8}$, choć przybiera różne formy - od poligamicznej do monogamicznej; od endogamicznej po egzogamiczną; od trwałej aż do śmierci współmałżonka po nietrwałą z powodu usankcjonowania rozwodów lub tzw. małżeństw czasowych; od zamieszkującej pod wspólnym dachem $\mathrm{z}$ rodziną męża lub żony po neolokalny typ zamieszkiwania; od wielopokoleniowej po dwupokoleniową; od patrylinearnej po matrylinearną; od przedindustrialnej po postindustrialną itp.

W Europie - obszarze oddziaływania kultury klasyczno-chrześcijańskiej - kształtował się typ/model rodziny opartej na monogamii, trwałej, otwartej na płodność, powiązanej silnymi więziami o różnorodnym charakterze ${ }^{9}$. Wprawdzie w ciągu wielu wieków pod wpływem procesów społecznych (np. industrializacji oraz urbanizacji) ulegał on powolnym zmianom polegającym na przejściu m.in. od rodziny wielkiej (agrarnej) do rodziny małej (industrialnej), to jednak ten typ przetrwał w świecie zachodnim do połowy XX wieku, wytyczając wyraźne granice normy i patologii, akceptacji

8 Uniwersalność rodziny - zdaniem antropologów kulturowych George’a P. Murdocka oraz Kathleen Gough - polega na jej użyteczności w spełnianiu celów koniecznych do przetrwania gatunku i społecznej kontynuacji, co wiąże się z powszechnym wypełnianiem czterech podstawowych funkcji (seksualnej, reprodukcyjnej, socjalizującej oraz ekonomicznej) oraz ze stosowaniem czterech zasad powszechnie związanych z rodziną w postaci: 1) zakazu stosunków seksualnych i małżeństwa pomiędzy bliskimi krewnymi, 2) zjawiska współpracy mężczyzn i kobiet w ramach podziału pracy wyznaczanego płcią, 3) wysokiego poziomu znaczenia nadawanego instytucji małżeństwa, choć niekoniecznie rozumianego jako związek mężczyzny i kobiety na całe życie, 4) posiadania wyższego statusu i autorytetu w rodzinie przez mężczyzn. Por. F. Adamski, Rodzina. Wymiar społeczno-kulturowy, dz. cyt.; T. Bielicki, Struktura rodziny ludzkiej w perspektywie antropologicznej, w: Rodzina - jej funkcje przystosowawcze i ochronne, red. E. Hałoń, Warszawa 1995, s. 9-22; A. Kwak, Uniwersalność instytucji rodziny i kierunki jej przemian, „Roczniki Socjologii Rodziny” 14 (2002), s. 9-23; J. H. Turner, Socjologia. Koncepcje i ich zastosowanie, tłum. E. Różalska, Poznań 1998.

9 Warto jednak pamiętać, iż realizacja dwóch z wyżej wymienionych cech (trwałości i płodności) w praktyce co najmniej do końca XVIII wieku była ograniczona wysoką śmiertelnością dorosłych i dzieci. Por. J.-L. Flandrin, Historia rodziny, dz. cyt. Natomiast więzi rodzinne oraz ich przemiany opisane są w książce: E. Budzyńska, 2018, Międzypokoleniowe więzi w rodzinie. Studium socjologiczne rodzin polskich i słowackich, dz. cyt. 
i potępienia społecznego oraz religijnego. Poza granicą owego normatywnego ideału znalazły się: przedmałżeńskie kontakty seksualne, konkubinat, cudzołóstwo i rozwód, pozamałżeńskie rodzicielstwo, aborcja i dzieciobójstwo, związki homoseksualne, co nie oznacza, że przekraczanie owych norm obyczajowo-religijnych (a także prawnych) nie miało miejsca. Takie przypadki jednak były albo skrzętnie skrywane albo - w razie ujawnienia na ogół spotykały się z mniej lub bardziej surowymi sankcjami ${ }^{10}$.

Od połowy XX wieku natomiast pod wpływem wielu procesów kulturowych rozpoczął się okres bardzo głębokich i szybkich przemian zachodzących w rodzinie zachodniej. W konsekwencji typ rodziny małżeńskiej, dzietnej i trwałej stał się jednym z wielu innych - opcjonalnych - typów rodziny, co więcej, przestaje on być uznawany za normatywny wzorzec. W związku z tym zachowania, które do niedawna spotykały się z potępieniem, zyskały status normalności. Do powyższych przemian przyczyniły się pewne zjawiska: w latach 60. XX wieku w wielu krajach zachodnich pod wpływem tzw. rewolucji seksualnej uwolniono seks od „przymusu małżeństwa”, złamano tabu kazirodztwa i zakaz pedofilii; pod wpływem subkultury hippisowskiej zaczęto akceptować używanie narkotyków, przyjęto za prawdziwe hasła feministek głoszące, że „mężczyźni to patriarchalni machos, kobieta jako żona i matka jest uciśniona i niepełnowartościowa, a realizować się może tylko w pracy zawodowej i poprzez «wolny seks»"11, wprowadzono do użytku pigułkę antykoncepcyjną, zalegalizowano aborcję, zniesiono karalność

10 Por. E. Budzyńska, Koniec rodziny, jaką znamy?, dz. cyt., s. 282-283. Bardziej szczegółowe informacje na ten temat można odnaleźć w wielu pracach historyków rodziny. Zob. R. N. Bellah, R. Madsen, W. M. Sullivan, A. Swidler, S. M. Tipton, Skłonności serca. Indywidualizm i zaangażowanie po amerykańsku, tłum. D. Stasiak, P. Skurowski, Warszawa 2007; M. Barański, Rodzina od czasów najdawniejszych do końca XVIII wieku, dz. cyt., s. 23-51; M. Delimata, Dziecko w Polsce średniowiecznej, Poznań 2004; H. Gerlich, Wizerunek niewiasty cnotliwej w górnoślaskich przekazach międzygeneracyjnych - od schyłku XIX wieku do połowy XX wieku, w: Kobieta i małżeństwo. Społeczno-kulturowe aspekty seksualności. Wiek XIX i XX, red. A. Żarnowska i A. Szwarc, Warszawa 2004, s. 421-439; A. Szwarc, Rygorystyczne normy i swobodne obyczaje. Mał̇̇enstwo i związki pozamałżeńskie w opiniach ziemiańsko-arystokratycznej elity w połowie XIX wieku, w: Kobieta i małżeństwo, dz. cyt., s. 89-101; D. Żołądź-Strzelczyk, Dziecko w dawnej Polsce, Poznań 2002.

11 Por. G. Kuby, Globalna rewolucja seksualna. Likwidacja wolności w imię wolności, tłum. D. Jankowska, J. Serafin, Kraków 2013, s. 61. 
cudzołóstwa i czynów homoseksualnych, zniesiono zasadę orzekania winy $\mathrm{w}$ procedurze rozwodowej ${ }^{12}$.

Proces dekonstrukcji rodziny nie zakończył się wraz z wygaśnięciem „rewolucji seksualnej”, lecz od lat 80. XX wieku trwa po dzień dzisiejszy, a nawet przybiera na sile. Daje się w nim zauważyć wyraźny udział tzw. „agentów zmiany”. Należą do nich m.in. organizacje feministyczne, które doprowadziły do „uwolnienia” kobiet od małżeństwa, od tradycyjnych rodzinnych ról społecznych i prokreacji, czyli od poczętego dziecka (zwanego „ciązą"); środowiska gejowskie - walczące o uznanie homoseksualizmu za normę oraz o prawa do zawierania małżeństwa i adopcji dzieci, przedstawiciele nauk społecznych i psychiatrii, postrzegający rodzinę jako instrument opresyjności i patriarchalizmu, obciążający ją odpowiedzialnością za destrukcję osobowości jednostek i - co najważniejsze - podważający znaczenie płci biologicznej na rzecz subiektywnie odczuwanej i dowolnie wybieranej tzw. płci kulturowej (gender), światowe organizacje takie jak ONZ, WHO czy Unia Europejska, które poprzez akty prawne i międzynarodowe konferencje ludnościowe narzucają wszystkim krajom przyjęcie polityki antyrodzinnej i antynatalistycznej pod groźbą wycofania pomocy gospodarczej ${ }^{13}$. W konsekwencji pod wpływem wszystkich powyższych

12 Por. G. Kuby, Globalna rewolucja seksualna, dz. cyt.; M. A. Peeters, Globalizacja zachodniej rewolucji kulturowej. Kluczowe pojęcia, mechanizmy działania, tłum. G. Grygiel, Warszawa 2010.

13 Te kwestie szczegółowo poruszają m.in.: M. Schooyans, Aborcja a polityka, tłum. K. Deryło, Lublin 1991; M. A. Peeters, Globalizacja zachodniej rewolucji kulturowej, dz. cyt.; G. Kuby, Globalna rewolucja seksualna, dz. cyt. Autorzy ukazują etapy globalizacji polityki antyrodzinnej i antynatalistycznej zmierzającej do ograniczenia ludzkiej populacji, zmienienia koncepcji płciowości (ideologia gender), wprowadzenia różnorodności form rodziny oraz wskazują na szerokie gremium międzynarodowych instytucji zaangażowanych w propagowanie oraz finansowanie tych idei. Problem ten w syntetyczny sposób przedstawił w wywiadzie dla „Naszego Dziennika” prof. Piotr Jaroszyński: „za tym stoją organizacje globalistyczne, które dążą do tego, żeby kontrolować liczbę ludności na świecie. Według tych organizacji największym zagrożeniem na Ziemi jest sam człowiek, dlatego ludzi - w ich mniemaniu - ma być coraz mniej. Stąd też promocja seksualności w taki sposób, który wyklucza prokreację. Wszystko, co służy prokreacji albo ją blokuje, czy to w wymiarze biologicznym, czy $\mathrm{w}$ wymiarze psychicznym, duchowym, edukacyjnym, politycznym, jest wspierane. I to jest naczelna idea tego typu organizacji. (...) Chodzi o to, żeby społeczeństwa i rządy (...) uległy temu naciskowi i forsowały programy, które będą kontrolować poziom ludności na Ziemi, ale przede wszystkim go redukować". Strategia zniszczenia i konfliktu. Rozmowa z prof. Piotrem Jaroszyńskim, kierownikiem Katedry Filozofii Kultury i Sztuki KUL, „Nasz Dziennik” (2019) nr 173, s. 2. 
działań kolejne państwa zmieniają prawodawstwo na takie, które legalizuje wielość płci kulturowych, małżeństwa pomiędzy nimi z prawem do posiadania przez nie dziecka, nakazuje tzw. tolerancję, często wiążąc ją z zakazem wszelakiej krytyki środowisk LGBT i z zasądzaniem kar za „mowę nienawiści”, narzucają przymus tzw. edukacji seksualnej od najmłodszego wieku we wszystkich placówkach edukacyjnych, gwarantują powszechną dostępność technik ubezpładniania oraz aborcji w ramach tzw. praw człowieka ${ }^{14}$.

Trzeba podkreślić, iż równolegle do działań mających na celu dekonstrukcję dotychczasowego porządku społecznego opartego na tradycyjnej małżeńskiej rodzinie prowadzona jest dekonstrukcja języka i używanych dotychczas pojęć. W miejsce starych terminów wprowadza się nowe, często pochodzące $\mathrm{z}$ nauk weterynaryjnych, zoologicznych, a nawet $\mathrm{z}$ botaniki, albo też starym pojęciom nadaje się całkiem nowe znaczenia. Na przykład zamiast pojęcia „rodzice” używa się słowa „reproduktorzy”, miejsce „ojca” i „matki” zajmuje „rodzic A” i „rodzic B”. „Partner” (w domyśle: „życiowy”) zastępuje „małżonka”, w miejsce „odpowiedzialnego rodzicielstwa” wchodzi „zdrowie reprodukcyjne” (oznaczające aborcję i antykoncepcję), znika „autorytet rodziców”, a pojawiają się wyłącznie „prawa dziecka”. Określenia personalistyczne jak „dziecko prenatalne”, „nasciturus”, „dziecko nienarodzone”, „dziecko poczęte” zastępowane są terminami zdepersonalizowanymi, „odczłowieczonymi” - zoologicznymi, a nawet botanicznymi, jak „płód”,

14 Por. G. Kuby, Rewolucja genderowa. Nowa ideologia seksualności, tłum. M. Urban CSsR, D. Jankowska, Kraków 2007; G. Kuby, Globalna rewolucja seksualna, dz. cyt.; G. Kuby, Dzieci jako eksperyment seksualny. Obowiązkowa edukacja seksualna w szkołach pewna droga do zniszczenia rodziny i chrześcijaństwa, tłum. M. Czarnik, w: Dyktatura gender, Kraków 2014, s. 29-51; M. A. Peeters, Globalizacja zachodniej rewolucji kulturowej, dz. cyt.; M. A. Peeters, Gender - światowa norma polityczna i kulturowa. Narzędzie rozeznania, tłum. L. Woroniecki, Warszawa 2013. Michał Gierycz w analizach dotyczących wypracowywania przez państwo polityki moralności zwraca uwagę na istotne znaczenie procesu jurydyzacji w zmienianiu obowiązujących norm moralnych: „Badacze odnotowują mianowicie zjawisko całkowitego wykluczenia obywateli z procesu decyzyjnego poprzez rozstrzygnięcia spraw z zakresu polityki moralności przez organy sądowe. Oczywiście, rzec można, iż generalnie współczesne demokracje przeżywają jurydyzację wielu obszarów polityki. Tym niemniej nietrudno zauważyć, iż moral policy stanowi przedmiot istotnych decyzji sądowych nawet w krajach, gdzie się to rzadko zdarza (Austria, Szwecja)”. M. Gierycz, Europejski spór o człowieka. Studium z antropologii politycznej, Warszawa 2017, s. 293. Bywa też, że sądowe decyzje, przyjmowane nierzadko niewielką liczbą głosów, wywołują polityczny szok (np. decyzja amerykańskiego Sądu Konstytucyjnego z 2015 roku przyznająca przewagą jednego głosu (5:4) parom gejowskim prawo do zawierania małżeństw w USA. M. Gierycz, Europejski spór o człowieka, dz. cyt., s. 293. 
„embrion”, „zarodek”, „tkanka płodowa”, „zapłodniona komórka jajowa”, „zlepek komórek”. Przykłady można mnożyć, gdyż każdy dzień dostarcza nowych, odgórnie narzucanych językowych „standardów”15 (zob. tabela 2).

Tabela 2. Lista tradycyjnych pojęć i ich współczesnych zamienników ${ }^{16}$

\begin{tabular}{|c|c|}
\hline Pojęcia tradycyjne & Pojęcia postmodernistyczne \\
\hline płeć (biologiczna) & gender (płeć kulturowa) \\
\hline $\begin{array}{l}\text { tożsamość płciowa wyzna- } \\
\text { czona biologicznie - męska } \\
\text { lub żeńska }\end{array}$ & $\begin{array}{l}\text { tożsamość płciowa możliwa do wyboru (i zmia- } \\
\text { ny) - z kilkudziesięcioma kategoriami pośredni- } \\
\text { mi pomiędzy biegunem męskim i żeńskim }\end{array}$ \\
\hline małżeństwo & $\begin{array}{l}\text { związek partnerski } \\
\text { (hetero- lub homoseksualny) }\end{array}$ \\
\hline małżonek/małżonka & partner/partnerka \\
\hline $\begin{array}{l}\text { rodzina } \\
\text { (małżeństwo z dziećmi } \\
\text { oraz krewni) }\end{array}$ & $\begin{array}{l}\text { związki partnerskie (hetero- lub homoseksual- } \\
\text { ne) z prawem do posiadania dzieci } \\
\text { (naturalnych, z in vitro lub adopcji) }\end{array}$ \\
\hline $\begin{array}{l}\text { rodzina tradycyjna } \\
\text { alternatywne formy } \\
\text { życia rodzinnego }\end{array}$ & $\begin{array}{l}\text { różnorodność rodzin (małżeńskich, niemał- } \\
\text { żeńskich, hetero-, homoseksualnych, pełnych, } \\
\text { niepełnych, patchworkowych itp.) }\end{array}$ \\
\hline $\begin{array}{l}\text { odpowiedzialne } \\
\text { rodzicielstwo }\end{array}$ & zdrowie reprodukcyjne (aborcja, antykoncepcja) \\
\hline ojciec, matka & rodzic $A$, rodzic $B$ \\
\hline rodzice & reproduktorzy \\
\hline
\end{tabular}

15 Por. G. Kuby, Globalna rewolucja seksualna, dz. cyt., s. 82-86; M. A. Peeters, Globalizacja zachodniej rewolucji kulturowej, dz. cyt., s. 42-46; M. Gierycz, Europejski spór o człowieka., dz. cyt., s. 314-327.

16 Źródło: opracowanie własne na podstawie: G. Kuby, Globalna rewolucja seksualna. Likwidacja wolności w imię wolności, tłum. D. Jankowska, J. Serafin, Kraków 2013, s. 82-86; M. A. Peeters, Globalizacja zachodniej rewolucji kulturowej. Kluczowe pojęcia, mechanizmy działania, tłum. G. Grygiel, Warszawa 2010, s. 42-46; M. Gierycz, Europejski spór o człowieka. Studium z antropologii politycznej, Warszawa 2017, s. 314-327. 


\begin{tabular}{|c|c|}
\hline Pojęcia tradycyjne & Pojęcia postmodernistyczne \\
\hline autorytet rodziców & prawa dziecka \\
\hline $\begin{array}{l}\text { dziecko poczęte, prenatalne, } \\
\text { nienarodzone, nasciturus }\end{array}$ & $\begin{array}{l}\text { płód, embrion, zarodek, tkanka płodowa, za- } \\
\text { płodniona komórka jajowa, zlepek komórek }\end{array}$ \\
\hline $\begin{array}{l}\text { zabójstwo dziecka } \\
\text { nienarodzonego }\end{array}$ & $\begin{array}{l}\text { aborcja, przerwanie (usunięcie) ciąży, } \\
\text { terminacja ciąży, wywołanie miesiączki }\end{array}$ \\
\hline $\begin{array}{l}\text { zabójstwo osoby niepełno- } \\
\text { sprawnej, chorej, starej }\end{array}$ & eutanazja, wspomagane samobójstwo \\
\hline $\begin{array}{l}\text { świętość życia - niepod- } \\
\text { ważalna wartość życia } \\
\text { ludzkiego }\end{array}$ & $\begin{array}{l}\text { jakość życia - } \\
\text { względna wartość ludzkiego życia }\end{array}$ \\
\hline $\begin{array}{l}\text { postawa pro-life, szacunek } \\
\text { dla ludzkiego życia (ze stro- } \\
\text { ny mężczyzn i kobiet) }\end{array}$ & $\begin{array}{l}\text { postawa pro-choice, wolność wyboru wyłącznie } \\
\text { kobiety. Szacunek dla życia zwierząt i roślin, wy- } \\
\text { kluczający szacunek dla życia ludzkiego }\end{array}$ \\
\hline
\end{tabular}

Podsumowując: o ile do połowy XX wieku rodzina małżeńska posiadała nienaruszalny status społeczny, etyczny, o tyle w drugiej połowie XX wieku pod wpływem działań wielu środowisk i organizacji głoszących radykalne hasła uwolnienia człowieka „od wszystkiego” (od rodziny, małżeństwa, rodzicielstwa, ograniczeń biologicznych własnej płci, norm moralnych dotyczących sfery seksualno-prokreacyjnej itd.), z wykorzystaniem instytucji politycznych, sądowniczych, środków masowego przekazu promujących nowe „style życia”, status ten został podważony, przekreślony, zaczęto natomiast akceptować i wprowadzać w życie różne typy związków realizujących prawa jednostki, niewymagające ani legalności, ani trwałości, ani wierności partnerów, ani dzietności, ani nawet heteroseksualności. W ten sposób w krajach zachodnich przyczyniono się do deinstytucjonalizacji rodziny tradycyjnej (nuklearnej) i jeśli nie do jej upadku, to przynajmniej do utraty jej znaczenia ${ }^{17}$.

17 Por. D. Popenoe, America's Family Problem, „The Public Perspective”, September/ October (1992), s. 22-24; D. Popenoe, War over the Family, New Brunswick-London 2005. 
Konsekwencją wyżej opisanych działań jest szybki proces pluralizacji i opcjonalizacji form życia rodzinnego: obok tradycyjnej trwałej rodziny małżeńskiej występują tzw. wielorodziny będące efektem monogamii seryjnej (zwanej również poligamią sukcesywną), ale też hetero- lub homoseksualne związki kohabitacyjne z dziećmi lub bez, zamieszkujące razem bądź osobno (np. LAT, czyli living apart together). W sferze rodzicielstwa obok tradycyjnych rodzin heteroseksualnych dwurodzicielskich pojawiają się rodziny monoparentalne lub odwrotnie $-\mathrm{z}$ multiplikacją rodziców biologicznych i społecznych: tych pierwszych - w wyniku upowszechnienia nowych technik reprodukcyjnych, tych drugich - w wyniku niekończącego się rozpadu małżeństw (bywa też, że obie przyczyny występują w tej samej rodzinie). Prócz tego obok coraz rzadziej występujących rodzin wielodzietnych funkcjonują rodziny małodzietne $-\mathrm{z}$ dwojgiem dzieci lub $\mathrm{z}$ jedynakiem - bądź małżeństwa (związki) bezdzietne. Ponadto w konsekwencji powtarzającej się $\mathrm{w}$ kolejnych pokoleniach małodzietności typ rodziny poszerzonej horyzontalnie zmienia się $\mathrm{z}$ jednej strony $\mathrm{w}$ typ rodziny poszerzonej wertykalnie (tzw. beanpole family), obejmującej trzy do czterech pokoleń, złożonych wyłącznie $\mathrm{z}$ krewnych w linii prostej. Z drugiej strony powszechne rozwody prowadzą do dalszego poszerzania tego typu rodzin o aktualnych lub byłych powinowatych (np. byłych mężów oraz ich aktualne lub byłe żony, a w konsekwencji o nowych i poprzednich "dziadków” lub „babcie”), nie wspominając o tzw. krewnych „przyszywanych”" ${ }^{18}$. W tym konglomeracie typów rodzin występujących w krajach zachodnich pojawia się jeszcze jeden typ, wcześniej nieobecny: są nim rodziny multikulturowe oraz rodziny światowe, do których wchodzą ludzie nie tylko różnej narodowości, różnych kultur i religii, ale także pochodzący z różnych kontynentów, często nieposiadający wspólnego gospodarstwa domowego, lecz kilka gospodarstw w kilku krajach ${ }^{19}$.

Następstwem wyżej opisanych zmian społecznych jest dostosowanie do nich terminologii $w$ naukach społecznych i wprowadzenie nowych, inkluzywnych definicji rodziny, które koncentrują się na motywacjach

18 Por. E. Budzyńska, Międzypokoleniowe więzi w rodzinie. Studium socjologiczne rodzin polskich $i$ słowackich, dz. cyt., s. 135-136.

19 Por. U. Beck, E. Beck-Gernsheim, Individualization. Institutionalized Individualism and its Social and Political Consequences, London-Thousand Oaks-New Delhi 2005; U. Beck, E. Beck-Gernsheim, Miłość na odległość. Modele życia w epoce globalnej, tłum. M. Sutkowski, Warszawa 2013. 
i preferencjach jednostek pozostających w osobistych relacjach. W tych ujęciach rodzinę postrzega się jako prywatną, dobrowolną grupę społeczną o szczególnych związkach. Jest nią zatem jakakolwiek grupa dorosłych i dzieci podtrzymujących wzajemne relacje, prowadzące do powstania uczuć i więzi rodzinnych ${ }^{20}$. Bywa jednak, że - jak zauważa Piotr Morciniec - w alternatywnej wobec klasycznej koncepcji rodziny „pojęcie rodziny nie jest tutaj w ogóle definiowane, ponieważ jej kształt zależy od preferencji jednostki. Rodzina jest osobistym projektem pojedynczego człowieka, w którym zarówno płeć partnera, jak też zasady życia wspólnego, np. czas trwania związku, są pozostawione samym zainteresowanym. Równocześnie - co jest ważne dla rozumienia rodziny - do głosu doszło nowe nastawienie do płodności, określane trafnie jako «ewolucja od imperatywu biologicznego do swobodnego wyboru»"21. W ten sposób rodzina nie tylko nie ogranicza się do małżeństwa i dzieci, ale obejmuje różne typy związków realizujących prawa jednostki. W takiej wizji nie musi się zawierać ani wymóg legalności, ani trwałości, ani wierności partnerów ${ }^{22}$. A zatem jeśliby chcieć dostosować do wymogów ponowoczesności przywołaną na początku artykułu klasyczną definicję rodziny, należałoby wykreślić z niej najbardziej istotne elementy i dodać takie, które podkreślałyby emocjonalne więzi zachodzące pomiędzy jednostkami oraz ewentualne wspólne zamieszkiwanie (zob. tabela 3).

Tabela 3. Ponowoczesna (inkluzywana) definicja rodziny

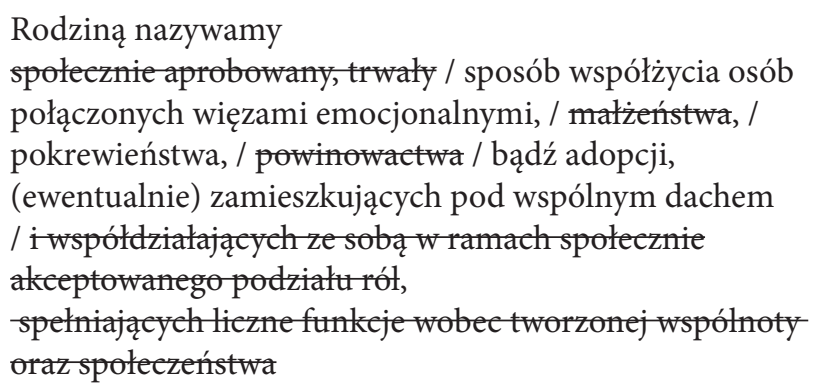

Źródło: opracowanie własne

20 Por. K. Slany, Alternatywne formy życia małżeńsko-rodzinnego w ponowoczesnym świecie, Kraków 2002, s. 80.

21 Por. P. Morciniec, Małżeństwo i rodzina $w$ zderzeniu z gender, w: Familiaris splendor. Piękno życia rodzinnego jako wyzwanie dla społeczeństwa i Kościoła, red. A. Bartoszek, Katowice 2011, Księgarnia św. Jacka, s. 75.

22 Por. P. Morciniec, Małżeństwo i rodzina $w$ zderzeniu z gender, dz. cyt., s. 75. 
Jak widać, w tym ujęciu do powstania "rodziny” nie jest potrzebne małżeństwo, gdyż wystarczy emocjonalne zaangażowanie, ewentualnie współzamieszkiwanie; nie jest też ważna trwałość więzi łączących członków rodziny $\mathrm{i}$ - tym bardziej - niepotrzebna jest społeczna aprobata dla nowego typu interpersonalnych „partnerskich” związków. Co więcej, jeśliby chcieć być zgodnym z głoszonymi hasłami feministek, ekologów, „genderystów”, należałoby zanegować większość pełnionych wcześniej przez rodzinę funkcji - zarówno wewnątrzgrupowych (osobowych), jak i zewnątrzgrupowych (instytucjonalnych). A zatem rodzina małżeńska heteroseksualna, wydając na świat potomstwo, już staje w konflikcie z zaleceniem „ideo-eko-logów” ograniczania populacji ludności. Ponadto dostarczając dzieciom tradycyjnych wzorców męskości i kobiecości (tożsamości płciowej, wzorów ról małżeńsko-rodzinnych), rodzina utrudnia młodemu pokoleniu wcielanie w życie założeń tzw. pakietu genderowego, mającego na celu zatarcie wszelkich różnic między płciami, zlikwidowanie tożsamości płciowej mężczyzny i kobiety oraz „przymusowej heteroseksualności” na rzecz uprzywilejowania związków pozaheteroseksualnych ${ }^{23}$. Poważnym utrudnieniem w realizacji ideologicznych celów staje się także funkcja socjalizacyjno-wychowawcza pełniona przez rodziców, gdyż utrwala w kolejnym pokoleniu religijne, tradycyjne wartości, normy i obyczaje, sprzeczne z tymi „nowoczesnymi” i „naukowymi" propagowanymi w mass-mediach i placówkach edukacyjnych. Podobnie negatywnie należałoby ocenić funkcję więziotwórczą rodziny, i to $z$ dwóch powodów. Po pierwsze ideałem dla ponowoczesnego społeczeństwa jest człowiek wolny od jakichkolwiek głębokich i trwałych zależności, dyspozycyjny, mobilny, oddany korporacjom, czyli ekonomicznie użyteczny ${ }^{24}$, po drugie zadaniem "nowoczesnych" matek jest realizowanie się wyłącznie w rolach zawodowych, zaś macierzyństwo i długotrwała więź z małym dzieckiem stoi z tym w jawnej sprzeczności ${ }^{25}$. Ostatnia kwestia, jaką jest wymiana

23 Por. G. Kuby, Dzieci jako eksperyment seksualny, dz. cyt., s. 29.

24 Por. K. Romaniszyn, Zaufanie w społeczeństwie uRynkowionym, w: Zaufanie społeczne. Teoria - idee - praktyka, red. J. Szymczyk, Warszawa 2016, s. 114.

25 Za przykład takiego stanowiska może służyć opinia Stevena Saxonberga dotycząca polityki rodzinnej w państwach postkomunistycznych: „Podczas gdy dzieci teoretycznie uzyskały prawo do posiadania obojga rodziców, wciąż niewiele zostało zrobione, aby dać im prawo do opieki dziennej na wysokim poziomie (podkr. E. B.) w sytuacji, gdy ich rodzice muszą pracować. (...) W końcu, jeżeli chodzi o kobiety, to prawo do posiadania dzieci bez porzucania karier zawodowych nie zostało im w pełni zapewnione w państwach postkomunistycznych. (...) Postkomunistyczne polityki rodzinne próbowały wypchnąć kobiety 
międzypokoleniowego wsparcia i pomocy, także pozostaje w sprzeczności z założeniami tych ideologii, według których osoby wymagające opieki i wsparcia, jako ekonomicznie „bezwartościowe” i „kosztochłonne”, stanowią obciążenie dla państwa i opiekunów -należałoby zatem „uwolnić” od nich zarówno rodzinę, jak i społeczeństwo ${ }^{26}$. Do rozwiązania pozostaje jedynie problem „dostarczania” pracodawcom pracowników, ale tę potrzebę można będzie w niedalekiej przyszłości zaspokoić albo przez „wyprodukowanie” $\mathrm{w}$ in vitro właściwej ilości ludzi o odpowiednich parametrach biologicznych (genetycznych), albo przez całkowitą automatyzację produkcji przemysłowej, albo - w ostateczności - przez przyjęcie pewnej puli imigrantów, gwarantujących odpowiedni poziom usług lub produkcji przemysłowej.

$\mathrm{Z}$ powyższych powodów współcześnie tradycyjna rodzina jawi się jako wróg „postępu” i „nowoczesności”, stając się „ulubionym celem ataków osób rozchwianych seksualnie, erotomanów, homoseksualistów płci obojga, feministek oraz «wyznawców» ideologii gender"27.

W Polsce na razie radykalne zmiany w prawodawstwie małżeńsko-rodzinnym (legalizujące tzw. związki partnerskie oraz małżeństwa homoseksualne z prawem do adopcji dzieci) nie zostały dopuszczone przez

z powrotem do domów, jako że dostęp do wczesnej opieki nad dzieckiem we wszystkich czterech omawianych państwach jest zdecydowanie zbyt niski, aby umożliwić kobietom powrót do pracy, zanim ich dzieci osiągną wiek przedszkolny (...). W tym samym czasie (...) poczyniono niewielki wysiłek, by skłonić mężczyzn do współdzielenia zadań związanych z wychowaniem dziecka, co oznacza, że kobiety wybierające posiadanie dzieci są wciąż zmuszone do ponoszenia podwójnych ciężarów pracy płatnej i bezpłatnej”. S. Saxonberg, Polityki rodzinne w nowych panstwach członkowskich Unii Europejskiej i ich wplyw na role wynikajace $z$ ptci oraz prawa jednostki, tłum. M. Kocik, w: Przemiany rodziny w Polsce $i$ we Włoszech i ich implikacje dla polityki rodzinnej, red. E. Leś i S. Bernini, Warszawa 2010, s. 113-114. Nad podobnymi rozwiązaniami zastanawiał się także Ulrich Beck, który dostrzegł znaczenie dla wychowania dziecka pomocy sąsiedzkiej lub specjalnie zatrudnianej „matki dziennej” w łagodzeniu sprzeczności pomiędzy rodziną i rynkiem pracy. Por. U. Beck, Społeczeństwo ryzyka. W drodze do innej nowoczesności, tłum. S. Cieśla, Warszawa 2002, s. 190. Jedynie Francis Fukuyama żywił cichą nadzieję, iż pod wpływem zmian kulturowych społeczeństwo informatyczne stanie się bardziej przyjazne dla dzieci, a możliwość przerwania pracy zawodowej na kilka lat, by je wychować, będzie kiedyś symbolem wysokiego statusu społecznego i finansowego rodziny. Por. F. Fukuyama, Wielki Wstrzas. Natura ludzka a odbudowa porządku społecznego, tłum. H. Komorowska, K. Dorosz, Warszawa 2000, s. 247.

26 Por. W. J. Smith, Kultura śmierci. Gdy medycynie wolno szkodzić, tłum. M. Reda, Kraków 2019.

27 Por. W. Roszkowski, Roztrzaskane lustro. Upadek cywilizacji zachodniej, Kraków 2019, s. 485. 
prawicowy rząd Prawa i Sprawiedliwości, niemniej jednak po zmianie ustrojowej w 1989 roku doszło do istotnych przemian w obrębie rodziny oraz w postrzeganiu jej wartości - podobnych do tych, które wcześniej pojawiły się w krajach zachodnich. Według Rafała Boguszewskiego zmiany te są wielokierunkowe: 1) opóźnia się wiek zawierania małżeństw, 2) wzrasta liczba rozwodów i separacji, 3) ludzie częściej decydują się na życie w pojedynkę, 4) coraz większą popularnością cieszą się też alternatywne formy życia małżeńskiego - w tym głównie związki kohabitacyjne, 5) coraz częstszym zjawiskiem są rodziny niepełne, samotni rodzice wychowujący dzieci oraz rodziny zrekonstruowane (tzw. patchworkowe), 6) zmniejsza się skłonność do posiadania dzieci, a decyzja o urodzeniu dziecka jest odkładana w czasie, 7) wzrasta liczba dzieci rodzonych poza małżeństwem, 8) w związku z powyższymi trendami zmieniają się również sposoby myślenia o małżeństwie i rodzinie, 9) liberalizacji podlegają opinie dotyczące różnych zjawisk i zachowań związanych zarówno z życiem małżeńskim, jak i rodzinnym ${ }^{28}$. Dla celów niniejszego opracowania wybierzemy najważniejsze $\mathrm{z}$ tych fenomenów, które najsilniej rzutują na funkcjonowanie społeczeństwa polskiego.

a) Opóźnienie wieku zawierania małżeństw - o ile w latach 1980-1990 średni wiek nowożeńców wynosił 24,4-24,7 lat, o tyle od 2010 roku zaczął się podnosić, by w 2018 roku osiągnąć wiek 30,0 lat ${ }^{29}$. Jednocześnie blisko 2/3 (61 proc.) Polaków akceptuje odkładanie decyzji o małżeństwie przez młodych ludzi, a nawet rezygnację z jego zawarcia. Daje się też zauważyć nieznaczny wzrost akceptacji dla życia w pojedynkę: z 44 proc. w 2013 roku do 49 proc. w 2019 roku $^{30}$. Zapewne przyczyn odkładania decyzji małżeńskich jest wiele, ale jedną $\mathrm{z}$ nich jest zmiana nastawienia pokolenia młodzieży wobec planowania własnej przyszłości: wiele młodych osób nastawia się bardziej na edukację, zrobienie profesjonalnej kariery, która wymaga coraz większego zaangażowania, dyspozycyjności i doskonalenia zawodowego, niż na związanie się na stałe $z$ drugą osobą, założenie rodziny i jej powiększenie ${ }^{31}$. W opinii dorosłych Polaków jednak inne motywy odkładania

28 Por. B. Boguszewski, Alternatywne modele życia rodzinnego $w$ ocenie społecznej. Komunikat z badań, Warszawa 2019.

29 Por. Rocznik Demograficzny GUS, Warszawa 2019, s. 185.

30 Por. B. Boguszewski, Alternatywne modele życia rodzinnego w ocenie społecznej, dz. cyt.

31 Por. M. Niezgoda, Młodzież. Kłopotliwa kategoria socjologiczna, „Jagiellońskie Studia Socjologiczne” (2014), s. 25; Sytuacja demograficzna Polski do 2018 roku. Tworzenie i rozpad rodzin, Warszawa 2019, 60. 
w czasie małżeństwa występują u kobiet, a inne u mężczyzn. Zdaniem respondentów kobiety kierują się głównie obawą przez nieudanym małżeństwem (42 proc.), postrzeganiem rodziny jako przeszkody w robieniu kariery zawodowej (40 proc.), dążeniem do życia bez zobowiązań (37 proc.), ewentualnie trudnościami ze znalezieniem odpowiedniego kandydata na męża (35 proc.). Bardziej egoistyczne motywy przypisywane są przez respondentów mężczyznom ociągającym się z założeniem rodziny: za najczęstszą przyczynę uznawany jest wybór tzw. wolności - życia bez zobowiązań (54 proc.), rzadziej - preferowanie przez mężczyzn życia w związku nieformalnym (37 proc.), trudności ze znalezieniem odpowiedniej kandydatki na żonę (30 proc.) lub lęk przed obowiązkami rodzicielskimi (28 proc.) ${ }^{32}$.

Jakiekolwiek motywy nie decydowałyby jednak o odkładaniu decyzji o założeniu rodziny lub całkowitej z niego rezygnacji, skutek dla społeczeństwa i państwa jest negatywny, gdyż w konsekwencji zjawisko to przyczynia się do zmniejszania się odsetka nowozakładanych rodzin, a w efekcie - do pogłębiającej się depopulacji polskiego społeczeństwa oraz do utrwalania postaw egoistycznych, skoncentrowanych na wartościach służących głównie jednostce.

b) Zjawisko rozwodów i separacji jest jeszcze groźniejsze w swych skutkach niż opóźnianie decyzji o założeniu rodziny, gdyż powoduje bardzo szerokie konsekwencje dla członków rodziny, zwłaszcza dla dzieci, ale także dla całego społeczeństwa. Po roku 2004 każdego roku rozwiodło się od 67 do 62 tysięcy małżeństw - najczęściej nieposiadających małoletnich dzieci (42 proc.) bądź posiadających tylko jedno dziecko (35 proc.), rzadziej dwoje (19 proc.) lub więcej (4 proc.) ${ }^{33}$. Do liczby rozwodów należy dodać liczbę separacji (w 2018 roku było ich 1284). Rozwody przyczyniły się więc wydatnie do wzrostu odsetka rodzin niepełnych z niepełnoletnimi dziećmi, najczęściej pozbawionych stałej obecności ojca, oraz do poszerzenia się zjawiska tzw. rodzin zrekonstruowanych (patchworkowych). Trzeba dodać, że liczba małoletnich dzieci z rozwiedzionych małżeństw sięga corocznie ponad 50 tysięcy ${ }^{34}$.

Postawy społeczne Polaków wobec coraz częstszych rozwodów powoli się zmieniają w kierunku coraz większej aprobaty. O ile w 2008 roku 62 proc.

\footnotetext{
32 Por. B. Boguszewski, Alternatywne modele życia rodzinnego w ocenie społecznej, dz. cyt.

33 Rocznik Demograficzny GUS, Warszawa 2019.

34 Por. Sytuacja demograficzna Polski do 2018 r. Tworzenie i rozpad rodzin, dz. cyt., 105.
} 
dorosłych Polaków dopuszczało rozwody, choć ich nie popierało, o tyle w 2018 roku odsetek takich osób zmalał do 52 proc. Podobnie zmniejszył się odsetek zdecydowanych przeciwników rozwodów - z 15 proc. w 2008 roku do 12 proc. w 2018 roku. Powoli zwiększa się natomiast odsetek zwolenników rozwodów, którzy wychodzą z założenia, że jeśli oboje małżonkowie zdecydują się na rozwód na drodze sądowej, nie powinni mieć ku temu żadnych przeszkód (z 20 proc. w 2008 roku do 32 proc. w 2018 roku) ${ }^{35}$. Interesujące jest również uzasadnienie rozwodów: dla 71 proc. istotne jest dążenie do własnego szczęścia: jeśli ono jest nieosiągalne w danym małżeństwie, należy się rozwieść i próbować ułożyć życie na nowo. Nieco rzadsza jest postawa oceniająca rozwód jako zło i przekonanie, że o małżeństwo zawsze walczyć ( 67 proc.). Tylko 24 proc. badanych uważa, że rozwody są grzechem, a w małżeństwie należy pozostać mimo występujących problemów. Jedynie 43 proc. respondentów uwzględnia dobro dzieci jako motyw pozostania w związku mimo braku porozumienia między rodzicami, a dla 62 proc. brak dzieci tym bardziej upoważnia do rozstania ${ }^{36}$. Wyniki tych badań wyraźnie wskazują na wzrost aprobaty rozwodu i postrzegania go jako rozwiązania lepszego niż podtrzymywanie skonfliktowanego związku małżeńskiego. Wprawdzie 2/3 respondentów dostrzega w rozwodzie moralne zło, ale tylko czwarta część badanych opowiada się za oceną religijną rozwodu jako grzechu połączoną z brakiem nań przyzwolenia. Wyniki tych badań świadczą o niezbyt dużym wpływie nauczania Kościoła katolickiego na postawy Polaków wobec ewentualności rozpadu małżeństwa.

Rozstanie się małżonków nie stanowi jedynie aktu prawnego, lecz jest zjawiskiem wielowymiarowym, na co zwrócił uwagę ks. Władysław Majkowski, wyróżniając oprócz rozwodu prawnego - rozwód emocjonalny (przybierający postać konfliktów; poczucia klęski, braku spełnienia, frustracji, straty), rozwód ekonomiczny (obejmujący podział majątku i alimenty na dzieci), rozwód rodzicielski (związany z decyzją sądu dotyczącą sprawowania opieki nad dzieckiem (bądź ograniczenia kontaktów z dzieckiem jednemu z rodziców), rozwód psychiczny (rozumiany jako proces oddzielenia swojego „ja” od osobowości i oddziaływania byłego współmałżonka (np. w postaci zdobycia umiejętności polegania wyłącznie na sobie, do bycia sam na sam ze sobą), wreszcie rozwód środowiskowy - z sąsiadami i przyjaciółmi,

35 Por. R. Boguszewski, Stosunek Polaków do rozwodu, Warszawa 2019.

36 Por. R. Boguszewski, Rozwody w osobistych doświadczeniach Polaków, Warszawa 2019. 
polegający na zerwaniu z nimi kontaktów ${ }^{37}$. Powyższe wymiary nie obejmują jednakże wszystkich konsekwencji rozwodu, które uderzają nie tylko w dorosłych, ale przede wszystkim w dzieci. Wskazuje na to wiele badań, z których wynika, że dzieci rozwiedzionych rodziców przejawiają liczne zaburzenia w sferze zdrowia psychicznego, jak m.in. neurotyzm, agresję, bierność, depresję, samobójstwa (60 proc. dzieci), częstsze uzależnienia od narkotyków i alkoholu przed 14 rokiem życia (ponad 50 proc. dzieci), wczesną aktywność seksualną, zwłaszcza u dziewcząt (prawie 100 proc. dzieci), połączoną ze wzrostem ilości młodocianych ciąż, aborcji lub urodzeń dzieci, konflikty z ojcem (65 proc.) i matką (30 proc.), wyższe wskaźniki antyspołecznych zachowań, przestępczości, poczucie mniejszej atrakcyjności w grupie oraz zaniżoną samoocenę, trudności z ukończeniem szkoły średniej (25 proc.). Do skutków rozwodu należy także utrata poczucia ciągłości życia, poczucia bezpieczeństwa, a przede wszystkim ograniczenie lub utrata kontaktu z rodzicem, z którym dziecko nie mieszka. To ostatnie zjawisko stanowi źródło wielu trudności emocjonalnych dzieci, do których zalicza się poczucie braku akceptacji, odrzucenia, a zwłaszcza trudności w identyfikacji w roli psychoseksualnej. Negatywne skutki rozwodu dla dzieci wiązane są z nieobecnością ojców w życiu rodzinnym, gdy opieka nad dzieckiem przyznawana jest przede wszystkim matce, a ojciec otrzymuje jedynie prawo do krótkich widzeń z dzieckiem bądź z nich w ogóle rezygnuje. Wzrastanie w rodzinie pozbawionej ojca (dotyczy to także rodzin tworzonych przez niezamężne matki) przyczynia się do wielu innych dramatycznych skutków w rozwoju psychospołecznym dzieci, w postaci np. gorszych wyników w szkole i niższych osiągnięciach, szkolnych absencji, popełniania ciężkich przestępstw, uzależniania od narkotyków i alkoholu, zaburzeń odżywiania, depresji, większej wrażliwości na stresy i zranienia, wyższego poziomu agresji i egoizmu, wczesnych związków seksualnych, wczesnych małżeństw, wczesnego rodzicielstwa i rozwodu, skłonności do stawania się ofiarą znęcania lub zaniedbań. Nie można też wykluczyć wpływu na wystąpienie powyższych zaburzeń atmosfery niezgody i dysharmonii poprzedzającej rozwód rodziców i towarzyszącej mu. Ponadto wszystkie te czynniki przyczyniają się do powstania tzw. śpiącego efektu rozwodu - ujawniającego się dużo

37 Por. W. Majkowski, Czynniki dezintegracji współczesnej rodziny polskiej. Studium socjologiczne, Kraków 1997. 
później w stosunku do terminu rozwodu ${ }^{38}$. Do długiej listy porozwodowych zaburzeń zdrowia psychicznego u dzieci należy dołączyć konsekwencje występujące w późniejszym okresie życia w postaci problemów w nawiązywaniu kontaktów społecznych, zwłaszcza w utrzymywaniu stałych związków z ludźmi, nieufność wobec ludzi, skłonności do „dziedziczenia rozwodów” lub „ucieczki” w tzw. wolne związki bądź kohabitację, wynikających z lęku przed małżeństwem i jego rozpadem ${ }^{39}$.

Jeśli powyższe dramatyczne skutki rozwodu dotykają każdego roku ponad 50 tysięcy dzieci, można spodziewać się, że w niedalekiej przyszłości duża część pokolenia młodych Polaków będzie przejawiać także w życiu

38 Por. D. Dobkowska, Więzi uczuciowe w rodzinie zrekonstruowanej, w: Materiały do nauczania psychologii, red. L. Wołoszynowi, Warszawa 1984, seria 2, t. 11, s. 363-464; E. Kozdrowicz, Sytuacja dziecka w rodzinie matki samotnej. Skrypt dla studentów pedagogiki, Warszawa 1989; F. R. Elliot, The Family: Change or Continuity?, London 1986; S. Lis, Proces socjalizacji dziecka $w$ środowisku pozarodzinnym, Warszawa 1992; W. Majkowski, Czynniki dezintegracji współczesnej rodziny polskiej, dz. cyt.; D. M. Newman, L. Grauerholz, Sociology of Families, Thousand Oaks-London-New Delhi 2002; J. S. Wallerstein, S. Blakeslee, Rozwód. A co z dziećmi?, tłum. C. E. Urbański, Poznań 2003; P. R. Amato, Family Change: Decline or Resilience?, w: Sourcebook of Family Theory \& Research, ed. V. L. Bengston, A. C. Acock, K. R. Allen, P. Dilworth-Anderson, D. M. Klein, Thousand Oaks-London-New Delhi 2005; E. M. Hetherington, The Adjustment of Children in Divorced and Remarried Families, w: Sourcebook of Family Theory \& Research, dz. cyt., s. 137-142; A. Kwak, Rodzina i jej przemiany, Warszawa 1994; A. Kwak, Rodzina $w$ dobie przemian. Małżeństwo i kohabitacja, Warszawa 2005; F. F. Furstenberg, A. J. Cherlin, Divided Families: What Happens to Children When Parents Part, Cambridge 1991; B. Józefik, Problematyka rozwodu i rodzin rekonstruowanych - implikacje terapeutyczne, „Państwo i Społeczeństwo” 3 (2005), s. 169-175.

39 Por. W. Majkowski, Czynniki dezintegracji współczesnej rodziny polskiej, dz. cyt.; I. Hałgas, Scenariusze nie-małżeńskie, „Tygodnik Powszechny” 13 (2000), s. 16; J. S. Wallerstein, S. Blakeslee, Rozwód. A co z dziećmi?, dz. cyt.; P. R. Amato, Family Change, dz. cyt.; A. Kwak, Rodzina $w$ dobie przemian, dz. cyt., M. Stankowska, Długoterminowa konsekwencje rozwodu. Problemy dorosłych dzieci z rodzin rozwiedzionych, w: Wielość spojrzeń na małżenstwo i rodzinę, red. A. Kwak, M. Bieńko, Warszawa 2012, s. 147-176. Należy jednak zwrócić uwagę, iż nie brakuje w literaturze przedmiotu takich badań oraz interpretacji, które dostrzegają u dzieci wychowywanych w rodzinach niepełnych bardziej pozytywne cechy niż u dzieci z rodzin pełnych, np. większą autonomię, elastyczność i hart psychiczny, umiejętność podejmowania decyzji, poczucie większej kontroli nad swoim życiem, niższy poziom stereotypizacji przyjmowanych ról płciowych i, co najważniejsze, wyniesione doświadczenie, że nawet najściślejsze więzy nie trwają wiecznie i mogą zostać zerwane, a separacja jest normalnym wydarzeniem w życiu. Por. U. Beck, E. Beck-Gernsheim, Individualization, dz. cyt. Trudno się zgodzić z takim stanowiskiem, gdyż stoi ono w jawnej sprzeczności z koncepcją zdrowia psychicznego, u którego podstaw leży zaspokojenie podstawowych potrzeb psychicznych, w tym potrzeby bezpieczeństwa i emocjonalnego kontaktu. 
dorosłym różnego typu zaburzenia $\mathrm{w}$ sferze psychicznej i społecznej np. w postaci depresji, nerwic, chorób psychosomatycznych, samobójstw itd., co z kolei będzie rzutować na pojawienie się dysfunkcji w życiu zawodowym i rodzinnym ${ }^{40}$.

c) Kohabitacja, czyli nieformalny związek mężczyzny z kobietą (niezalegalizowany, niemałżeński), to kolejne zjawisko społeczne, które się upowszechnia i zyskuje coraz większą społeczną aprobatę także w Polsce. Według danych spisowych liczba partnerek/partnerów wzrosła o prawie $2 / 3$ (z niespełna 400 tysięcy w 2002 roku do prawie 650 tysięcy w 2011 roku) - co oznacza wzrost liczby związków kohabitacyjnych z prawie 200 tysięcy w 2002 roku do ok. 320 tysięcy w 2011 roku. Na razie udział tych osób w całej populacji dorosłych Polaków nie jest znaczący i wynosi 2 proc. ${ }^{41}$, jednak daje się już zaobserwować rosnącą popularność tego typu związków. W populacji kohabitantów „dominującą część - 62 proc. - stanowią osoby o stanie cywilnym prawnym kawaler/panna. Drugą grupą są osoby rozwiedzione (28 proc.), a osoby pozostające $\mathrm{z}$ prawnego punktu widzenia w małżeństwie oraz osoby owdowiałe stanowią po 5 proc. ogółu partnerek i partnerów. Jest to niewątpliwie związane z wiekiem osób kohabitujących. Nastoletni i dwudziestoletni partnerzy to przede wszystkim kawalerowie i panny, ale już wśród trzydziestoletnich kohabitantów drugą pod względem liczebności grupą są osoby rozwiedzione. Rozwiedzeni stanowią także ponad połowę spośród czterdziesto-, pięćdziesięcio- i sześćdziesięcioletnich partnerów oraz czterdziesto- i pięćdziesięcio-letnich partnerek" ${ }^{\prime 2}$. Z badań nad postawami wobec tzw. alternatywnych związków wynika, że w ciągu ostatnich jedenastu lat ubyło zwolenników zawierania małżeństw przez osoby żyjące ze sobą bez ślubu (60 proc. w 2008 roku i 52 proc. w 2019 roku), natomiast wzrosła aprobata dla związków niemałżeńskich (z 38 proc. w 2008 roku do 45 proc. w 2019 roku), opartych wyłącznie na miłości i zaufaniu. Przeciwnikami zawierania małżeństw są przede wszystkim osoby stanu wolnego (łącznie 57 proc.) oraz po rozwodzie (łącznie 60 proc.),

40 Zob. P. C. Vitz, Family Decline: The Findings of Social Science, 1999, www. catholiceducation.org/en/controversy/marriage/family-decline-the-findings-of-socialscience.html (04.03.2014); D. Popenoe, America’s Family Problem, dz. cyt., s. 22-24.

41 Por. Ludność. Stan i struktura demograficzno-społeczna. Narodowy Spis Powszechny Ludności i Mieszkań, Warszawa 2013, s. 61-73.

42 Ludność. Stan i struktura demograficzno-społeczna, dz. cyt., s. 71. 
natomiast zwolennikami częściej są osoby owdowiałe (łącznie 56 proc.) lub żyjące w małżeństwie (łącznie 57 proc.) ${ }^{43}$.

Badacze wyróżniają wiele typów kohabitacji: przedślubną - poprzedzającą małżeństwo, alternatywną wobec małżeństwa, seryjną, tymczasową i in. Przyczyny kohabitowania są zróżnicowane - od obyczajowych i prawnych, przyzwalających na mieszkanie par bez ślubu, a nawet zrównujących w prawach i przywilejach oba typy związków ${ }^{44}$, poprzez kreowanie przez mass media związków alternatywnych jako bardziej atrakcyjnych i romantycznych, po uprzednie doświadczenia wyniesione z rodzin pochodzenia (dzieci z rodzin rozbitych lub kohabitujących konfliktowych częściej decydują się na kohabitację; szczególnie odnosi się to do młodych mężczy$\mathrm{zn})^{45}$. Z wielu badań nad związkami kohabitacyjnymi w porównaniu ze związkami małżeńskim wynika, że: 1) wybór kohabitacji jako formy życia $\mathrm{w}$ związku z drugą osobą jest powiązany silnie z preferowaniem wartości indywidualistycznych, negatywnych postaw wobec małżeństwa i prokreacji, gotowości do rozstania w razie niespełnienia oczekiwań przez partnera, częstszej dopuszczalności innych związków seksualnych pozakohabitacyjnych; 2) związek taki jest traktowany jako niezobowiązujący, niepewny, niewymagający głębokiego zaangażowania, za to dający możliwość spełniania się w sferze zawodowej, zaspokojenia potrzeb seksualnych przy jednoczesnym uwolnieniu od obowiązków i odpowiedzialności za „dom” i „rodzinę"; 3) związki kohabitacyjne wykazują niższy poziom poczucia szczęścia i dobrostanu (pomyślności) partnerów niż małżeństwa; 4) związki kohabitacyjne mają znacznie krótszy czas trwania w porównaniu ze związkami małżeńskimi; obserwuje się także szybszy rozpad małżeństw, które są poprzedzone kohabitacją w porównaniu ze związkami małżeńskimi niepoprzedzonymi współzamieszkiwaniem. Co więcej, im dłuższa kohabitacja poprzedzająca małżeństwo, tym większe prawdopodobieństwo szybkiego

43 Por. B. Boguszewski, Alternatywne modele życia rodzinnego w ocenie społecznej, dz. cyt.

44 Niektórzy badacze wyróżnili kilka stadiów rozpowszechnienia się zjawiska kohabitacji: w stadium pierwszym występuje ona jako zjawisko marginalne lub awangardowe, w stadium drugim - jako forma badania gruntu pod małżeństwo, w stadium trzecim - jest akceptowana i traktowana jako alternatywa wobec małżeństwa, a w stadium czwartym - staje się związkiem interpersonalnym, trudnym do odróżnienia od związku małżeńskiego. Por. J. Rostowski, Współczesne przemiany rozumienia związku małżeńskiego, dz. cyt., s. 36.

45 Por. I. Janicka, Związki kohabitacyjne, w: Psychologia rodziny, red. I. Janicka, H. Liberska, Warszawa 2014, s. 259-284. 
rozpadu zawartego później małżeństwa; 5) w porównaniu z małżeństwami dzietność związków kohabitacyjnych jest znacznie niższa; 6) w związkach kohabitacyjnych częściej niż w małżeństwach kobiety są ofiarami przemocy domowej; podobnie dzieci - znacznie częściej stają się ofiarami znęcania się fizycznego, emocjonalnego, seksualnego, zwłaszcza ze strony przybranego rodzica; 7) dzieci mają potrzebę życia w warunkach stabilności i trwałości rodzinnych relacji, a kohabitacja rodziców tego im nie zapewnia ${ }^{46}$.

Podsumowując kwestię konsekwencji wynikających z upowszechniania się kohabitacji i rodzin monoparentalnych, Jan Rostowski stwierdza: „Badania jednak dowodzą, że wzrost związków niemałżeńskich, a szczególnie rodzin z jednym rodzicem, przyczynia się do różnorodności występowania społecznych problemów, włącznie z ubóstwem, przestępczością, przemocą fizyczną, uzależnieniami, obniżaniem się standardów szkolno-akademickich, w pewnym stopniu także do zanikania więzów sąsiedztwa i społeczności, a w konsekwencji poważnych zagrożeń dla dobrego samopoczucia dzieci i dorosłych. Jedną z form przeciwdziałania występowaniu tych problemów jest tworzenie programów wspierających występowanie i funkcjonowanie zdrowych małżeństw"47.

Opisując skutki psychologiczne i społeczne funkcjonowania rodziny zrekonstruowanej po uprzednim rozwodzie (lub rozpadzie wcześniejszego związku kohabitacyjnego), nie można ponadto pominąć problemów wynikających ze skomplikowanych relacji zachodzących pomiędzy dziećmi i rodzicami - biologicznymi i przybranymi - oraz pomiędzy przybranym rodzeństwem. Trudności - wynikające ze specyficznej sytuacji ułożenia na nowo relacji z byłym i nowym małżonkiem, przyjęcia nowej roli macochy lub ojczyma, nawiązania kontaktów pomiędzy dziećmi pochodzącymi z wcześniejszych związków (ułożenia na nowo hierarchii pozycji społecznych)

\footnotetext{
46 Por. K. Slany, Alternatywne formy życia małżensko-rodzinnego $w$ ponowoczesnym świecie, dz. cyt.; E. M. Hetherington, The Adjustment of Children in Divorced and Remarried Families, dz. cyt., s. 137-142; A. Kwak, Rodzina w dobie przemian, dz. cyt.; I. Janicka, Związki kohabitacyjne, w: Psychologia rodziny, dz. cyt., s. 259-284; K. Juszczyk-Frelkiewicz, Kohabitacja w Polsce i na Słowacji. Studium socjologiczne, Katowice 2014; D. Popenoe, B. D. Whitehead, Should we live together? What Young Adults Need to Know about Cohabitation before Marriage. A Comprehensive Review of Recent Research, "Smart Marriages", The Coalition for Marriage, Family, and Couples Education, www.smartmarriages.com/cohabit. html (02.05.2010).

47 J. Rostowski, Współczesne przemiany rozumienia związku małżeńskiego, dz. cyt., s. 38.
} 
oraz ustosunkowania się wobec nowego potomka - przyczyniają się do wystąpienia głębokich konfliktów i kolejnego rozpadu rodziny ${ }^{48}$.

d) Badacze analizujący różnorakie skutki dokonujących się przemian społeczno-kulturowych rzutujących na funkcjonowanie rodzin oraz społeczeństwa wskazują na jeszcze jeden obszar, który na ogół umyka uwadze socjologów, natomiast coraz bardziej skupia na sobie zainteresowanie psychologów i psychoterapeutów. Tym obszarem są emocjonalne więzi łączące dziecko z rodzicami oraz skutki ich osłabienia, a nawet ich braku. $\mathrm{Z}$ badań psychologicznych i medycznych nad relacjami zachodzącymi pomiędzy matką i małym dzieckiem (w wieku do trzech lat) wynika, że jakość emocjonalnej więzi łączącej dziecko z matką rzutuje na całe późniejsze życie dziecka, także na okres dorosłości. Okazuje się, że doświadczanie przez dziecko matki, stanowiącej „bezpieczną bazę wypadową", stymuluje rozwój emocjonalny dziecka, podczas gdy niezaspokojenie jego pierwotnych potrzeb emocjonalnych przez matkę w postaci albo tzw. niedostrojenia emocjonalnego do dziecka (które ma miejsce w sytuacji niewłaściwie przebiegającej interakcji, gdy dziecko przejawia aktywność, a osoba dorosła - bierność), albo krócej bądź dłużej trwającego opuszczenia dziecka przez matkę (oddanie do żłobka, pod opiekę nowej opiekunki, do domu dziecka, do szpitala), powoduje dziecięcą reakcję w postaci poczucia zagrożenia, utraty poczucia bezpieczeństwa. To doświadczenie - deprywacji uczuciowej - staje się przyczyną wystąpienia wielu późniejszych dysfunkcji emocjonalnych, takich jak depresja, niepokój, skłonności samobójcze w życiu dorosłym, zaburzenia odżywiania, alkoholizm, otyłość czy podatność na wykorzystywanie seksualne ${ }^{49}$. Ponadto stres i separacja od matki osłabiają u dziecka rozwój układu odpornościowego i centralnego układu nerwowego, przyczyniając się do pojawienia wielu chorób somatycznych oraz dysfunkcji w sferze rozwoju poznawczego i emocjonalnego - w postaci objawów roztargnienia, zaburzeń

48 Por. E. M. Hetherington, The Adjustment of Children in Divorced and Remarried Families, dz. cyt., s. 137-142; A. Lewandowska-Walter, Znaczenie struktury i relacji rodzinnych dla jakości życia dziecka z rodziny zrekonstruowanej, w: Jakość życia rodzinnego. Wybrane zagadnienia, red. T. Rostowska, Łódź 2006, s. 185-197; P. C. Vitz, Family Decline: The Findings of Social Science, dz. cyt.

49 Por. M. Sunderland, Mądrzy rodzice, tłum. A. Wyszogrodzka-Gaik, Warszawa 2008; S. Gerhardt, Znaczenie miłości. Jak uczucia wpływają na rozwój mózgu, tłum. B. Radwan, Kraków 2010. 
myślenia logicznego, kontrolowania zachowania, ubóstwa inteligencji emocjonalnej i społecznej ${ }^{50}$.

Jak widać, skutki pierwotnej więzi matka-dziecko rozciągają się na całe życie jednostki, obejmując zarówno sferę poznawczą, relacji emocjonalnych, jak i - co ważne dla socjologa - warunkują jakość i trwałość więzi społecznych zwłaszcza w wymiarze mikrostrukturalnym (np. związków przyjaźni, miłości, małżeństwa, rodziny) ${ }^{51}$. Mało tego, jakość i wzory emocjonalnej więzi matka-dziecko powtarzają się w kolejnych pokoleniach, gdyż sposób, w jaki matka opiekuje się dzieckiem, pozostaje w wyraźnym związku z jakością przywiązania, jakie miało miejsce w jej wczesnym dzieciństwie między nią i jej własną matką. Świadczy to o międzypokoleniowym przekazie adaptacyjnych i dezadaptacyjnych stylów rodzicielstwa ${ }^{52}$.

Jak widać, stan współczesnej wiedzy psychologicznej i medycznej nie pozostawia złudzeń co do fundamentalnego znaczenia pierwotnej więzi emocjonalnej (ufnego przywiązania) dla zdrowia fizycznego, psychicznego i społecznego człowieka ${ }^{53}$. Jednak wiedza ta, niestety, nie przekłada się w żaden sposób ani na społeczną świadomość skutków deprywacji emocjonalnej

50 Por. M. Sunderland, Mądrzy rodzice, dz. cyt.; S. Gerhardt, Znaczenie miłości. Jak uczucia wpływaja na rozwój mózgu, dz. cyt.

51 Na podstawie wielu badań stwierdzono ponadto, iż brak opieki matczynej przyczynia się do wystąpienia u dziecka różnorodnych zaburzeń (tzw. choroba sieroca) zarówno w sferze fizycznej - w postaci np. opóźnienia rozwoju fizycznego, obniżenia odporności na infekcje, opóźnienia rozwoju motorycznego, stereotypowych ruchów (tzw. kiwanie się), jak i psychicznej - w postaci np. opóźnionego rozwoju umysłowego, infantylizmu uczuciowego, płytkości uczuć, a nawet psychopatii, apatii lub nadpobudliwości, agresji, braku empatii, tzw. lepkości polegającej na przywieraniu do każdej osoby dorosłej, moczenia nocnego, a w dorosłym wieku - skłonności do depresji, samobójstw, psycho- i socjopatii, niepowodzeń w życiu małżeńskim i zawodowym, konfliktów z prawem. Por. C. H. Paterson, S. C. Hidore, The Primary Prevention of Psychosocial Disorders: a Person/Client-centered Perspective, „The Person-Centered Journal" (1997) vol. 4, is. 1, www.sageofasheville.com/primary_prevention. html (09.03.2012); Ch. H. Zeanath, A. T. Smyke, S. F. Koga, E. Carlson, Attachement in Institutionalized and Community Children in Romania, „Child Development” 5 (2005), vol. 76, s. 1015-1028; J. McCall, Research on the Psychological Effects of Orphanage Care: A Critical Review, w: Rethinking Orphanages for the 21st Century, ed. R. B. McKenzie, Thousand Oaks, California 1999, Inc., s. 127-150, www.parentsinaction.net/english/Kidnaping/The_Psychological_Effects_of_Orphanage_Care.htm (09.03.2012); E. Jundziłł, Potrzeby psychiczne dzieci i młodzieży. Diagnoza - zaspokojenie, Gdańsk 2000; D. Goleman, Inteligencja emocjonalna, tłum. A. Jankowski, Poznań 1997.

52 Por. E. Budzyńska, Małe dzieci - mały kłopot?, dz. cyt., s. 93-135.

53 Por. L. Bowbly, Przywiązanie, tłum. M. Polaszewska-Nicke, Warszawa 2007; P. C. Vitz, Family Decline: The Findings of Social Science, dz. cyt. 
u małego dziecka, ani na politykę państwa wobec młodych matek, ani na lansowane wzorce ról społecznych. Współcześnie mamy natomiast do czynienia z propagowaniem wręcz intensywnej i długotrwałej pracy obydwojga rodziców, powierzania opieki nad małym dzieckiem na wiele godzin obcym osobom lub instytucjom ${ }^{54}$. Jeśli do tego dodać coraz dłuższy pobyt dzieci w szkole i coraz liczniejsze zajęcia pozaszkolne (lekcje muzyki, języków obcych, zajęcia sportowe), to w konsekwencji dramatycznie kurczy się wpływ rodziny na wychowanie dziecka i budowanie z nim głębokich więzi. Współczesne dzieci coraz mniej czasu spędzają zatem z rodzicami: matki tuż po urlopie macierzyńskim powracają do pracy zawodowej, ojcowie często są nieobecni, dziadkowie mieszkają daleko, nie ma więc komu zaspokoić najbardziej podstawowych potrzeb dziecka ${ }^{55}$. W efekcie nie tylko role rodzicielskie, ale i zakres pierwotnej socjalizacji, opartej na stałych, długotrwałych i silnych emocjonalnych więziach, zostają ograniczone do minimum. Co więcej, życie rodzinne przestało się dzisiaj toczyć w jednym stałym miejscu, często zostaje rozproszone pomiędzy kilkanaście różnych, straciło też stały rytm dnia na rzecz rytmu narzucanego przez wiele społecznych instytucji: np. żłobki, przedszkola, szkoły, organizacje młodzieżowe, godziny pracy męża i żony, godziny otwarcia sklepów, rozkład jazdy publicznego transportu itd. ${ }^{56}$. W efekcie dom rodzinny staje się pusty, jest miejscem noclegu, ewentualnie wypoczynku, a rzadko - wspólnej pracy ${ }^{57}$. Socjalizującą funkcję rodziny przechwytują natomiast podmioty pozarodzinne - środowiska rówieśnicze oraz internet, przekazując młodemu pokoleniu wartości dalekie od preferowanych przez rodzinę i pożądanych przez społeczeństwo.

Dokonujące się przemiany rodziny, jedynie zasygnalizowane w obecnym artykule, są różnorako interpretowane przez socjologów i polityków. Ci, którym bliski jest model rodziny małżeńskiej, pełnej i trwałej, którego wartość można uzasadnić społecznie i religijnie, zachodzące zmiany społeczne będą interpretować jako "upadek rodziny” (the family decline perspective). W tym podejściu interpretacyjnym podkreśla się liczne negatywne konsekwencje

54 Por. Opieka nad dziećmi do 3. roku życia w Polsce i na świecie. Aspekty prawne, ekonomiczne i społeczne. Raport Instytutu Ordo Iuris, red. T. Zych, A. Świerzewska, M. Olek, J. Roszkiewicz, Warszawa 2018.

55 Por. D. Popenoe, America's Family Problem, dz. cyt., s. 22-24.

56 Por. U. Beck, E. Beck-Gernsheim, Individualization, dz. cyt.

57 Por. A. Giza-Poleszczuk, Rodzina a system społeczny. Reprodukcja i kooperacja w perspektywie interdyscyplinarnej, Warszawa 2005. 
odchodzenia od kultury zobowiązań wobec innych ludzi oraz instytucji (w tym małżeństwa). Świadczy o nich choćby częstsze występowanie zaburzeń emocjonalnych, przestępczości, ucieczek ze szkoły, uzależnień, gwałtów, urodzeń pozamałżeńskich, a w efekcie - erozji sąsiedztwa i społeczności będących konsekwencją wzrostu liczby gospodarstw monoparentalnych ${ }^{58}$, ale także innych faktów takich jak upadek autorytetów, seksualny promiskuityzm wśród młodych, zanik instytucjonalności rodziny, zmiany w jej strukturze w postaci rozwodów i niezamężnego macierzyństwa, nieobecność ojców, zmniejszenie dzietności bądź rezygnacja z posiadania dzieci, praca zawodowa kobiet kolidująca $\mathrm{z}$ opieką nad dziećmi, a także ucieczka przed małżeństwem w kohabitację ${ }^{59}$. Natomiast zwolennicy odmiennej interpretacji przemian rodziny odwołują się do koncepcji „transformacji” bądź „pluralizacji form rodziny”, ewentualnie - stosując niezwykle szeroką definicję rodziny - będą opowiadać się za jej „prężnością” (the family resilience perspective). Zaprzeczają oni, jakoby zachodnia kultura dryfowała w kierunku coraz większego indywidualizmu i egoizmu. Według nich wątpliwe jest, by obecnie następował wzrost nieszczęśliwych małżeństw: zarówno dawniej, jak i współcześnie zawsze one występowały - z tą różnicą, iż w przeszłości otrzymanie rozwodu było kosztowne i angażowało dużo czasu, a ponadto spotykało się ze społecznym potępieniem. Współcześnie natomiast rozwód daje dorosłym osobom ponowną szansę na znalezienie szczęścia, a dzieciom - możliwość odejścia z dysfunkcjonalnego środowiska $^{60}$. Takie osoby uważają ponadto, że nie tyle struktura rodziny jest ważna, lecz procesy i stosunki zachodzące w rodzinie, nie tyle pełność rodziny, lecz rodzicielska piecza, zaangażowanie i wrażliwość na potrzeby dzieci są lepszymi wskaźnikami ich dobrostanu. Ponadto - według zwolenników tego stanowiska - rodzinę (także tę tradycyjną) zawsze trapiły różne nieszczęścia, które przyczyniały się do jej niestabilności - choćby częste sieroctwo dzieci spowodowane śmiercią rodziców oraz wychowywanie ich w rodzinie zrekonstruowanej, trudne losy „bękartów”, czyli dzieci ze związków pozamałżeńskich, spora liczba „starych panien i kawalerów”, niemających szans na małżeństwo z racji niskiego statusu i biedy; nie wspominając o tym, że

\footnotetext{
58 Por. P. R. Amato, Family Change, dz. cyt.

59 Por. U. Beck, E. Beck-Gernsheim, Individualization, dz. cyt., A. Kwak, Rodzina w dobie przemian, dz. cyt. D. M. Newman, L. Grauerholz, Sociology of Families, dz. cyt.; D. Popenoe, America's Family Problem, dz. cyt., s. 22-24; D. Popenoe, War over the Family, dz. cyt.

60 Por. P. R. Amato, Family Change, dz. cyt.
} 
każda $\mathrm{z}$ warstw społecznych tworzyła odmienne strategie tworzenia rodziny - od wczesnego zawierania małżeństw i rodzenia wielu dzieci po małżeństwa odłożone w czasie i małodzietność. Zatem zróżnicowanie form życia rodzinnego było faktem, tyle że powodowanym czynnikami obiektywnymi (śmierć, wojny, epidemie), a nie indywidualnym świadomym wyborem. W związku z tym przeciwnicy koncepcji „upadku rodziny” zastanawiają się, czy jej zwolennikom chodzi o konkretny typ rodziny (np. występujący w USA do latach 50. XX wieku), czy raczej o upadek mitu rodziny ${ }^{61}$.

Jednak ocena zmian współczesnej rodziny nie kończy się na interpretacyjnym sporze pomiędzy badaczami, ale wpływa także na kształt przyjętej przez państwo polityki społecznej wobec rodzin. Zwolennicy teorii upadku rodziny uważają, że - aby zapobiec negatywnym konsekwencjom wynikającym z dokonujących się przemian - należy rozwijać taką kulturę (i wychowanie), która będzie wspierać wartość rodziny i małżeństwa, akcentując wagę odpowiedzialności za małżonka i dzieci, która będzie wspierać rozwój poradnictwa na rzecz rodziny, ograniczać możliwość łatwego uzyskania rozwodu (np. bez orzekania winy), promować trwałość małżeństwa. Natomiast zwolennicy drugiego stanowiska sądzą, iż ubóstwo, bezrobocie, źle wyposażone szkoły i brak rządowych służb stanowią większe zagrożenia dla dobrego samopoczucia dzieci niż brak pełnej rodziny, zwłaszcza że dzieci rozwijają się prawidłowo niezależnie od struktury rodziny, w jakiej wzrastają. Dlatego nie należy wprowadzać polityki społecznej wspierającej długotrwałe małżeństwa i promującej wyłącznie jeden typ rodzin, ale inwestować w jakość opieki pozarodzinnej nad dziećmi ${ }^{62}$.

Z całą pewnością także polskie społeczeństwo i politycy stoją przed takim wyborem polityki rodzinnej. Powstaje pytanie, czy będą optować za wzmacnianiem wartości rodziny tradycyjnej, czy też ulegną nowym prądom, lansowanym nie tylko przez polskich zwolenników liberalizacji życia rodzinnego, ale mocno wspieranym przez organizacje międzynarodowe, których działalność została zasygnalizowana na początku artykułu. Jeśli

61 Por. A. Giza-Poleszczuk, Rodzina i system społeczny, w: Wymiary życia społecznego. Polska na przełomie XX i XXI wieku, red. M. Marody, Warszawa 2002, s. 272-301; A. Giza-Poleszczuk, Przestrzeń społeczna, w: Strategie i system. Polacy w obliczu zmiany społecznej, red. A. Giza-Poleszczuk, M. Marody, A. Rychard, Warszawa 2000, s. 97-166; L. Kocik, Wzory małżństwa i rodziny. Od tradycyjnej jednorodności do współczesnych skrajności, Kraków 2002; D. M. Newman, L. Grauerholz, Sociology of Families, dz. cyt.

62 Por. P. R. Amato, Family Change, dz. cyt. 
zwycięży opcja druga - wcielania w życie form skrajnego indywidualizmu w postaci prawa do wyboru różnych form życia intymnego - społeczeństwo polskie, podobnie jak społeczeństwa zachodnie, wkrótce doświadczy dramatycznych skutków w postaci postępującej singlizacji z wyboru, wynikającej z braku potrzeby zakładania rodziny, wzrostu częstości rozpadu małżeństw prowadzącego do występowania różnorakich, wcześniej opisanych, psychologicznych i społecznych konsekwencji, deficytu urodzeń, będącego skutkiem niechęci do posiadania dzieci (w przyszłości pociągnie to za sobą za sobą załamanie systemu podatkowego, ubezpieczeń społecznych oraz państwa opiekuńczego), starzenia się społeczeństwa, oznaczającego wzrost kosztów opieki zdrowotnej oraz państwowych wydatków na emerytury. Dalsze konsekwencje łatwo przewidzieć: starzejące się społeczeństwo, bez dzieci, opustoszałe domy, rozbite rodziny i brak wartości ${ }^{63}$. Może zatem warto przypomnieć i wcielić w życie słowa obrońcy rodziny - św. Jana Pawła II: „Przyszłość ludzkości idzie poprzez rodzinę! Jest zatem rzeczą nieodzowną i naglącą, aby każdy człowiek dobrej woli zaangażował się w sprawę ratowania i popierania wartości i potrzeb rodziny" 64 .

\section{Bibliografia}

Adamski F., Rodzina. Wymiar społeczno-kulturowy, Kraków 2002.

Amato P. R., Family Change: Decline or Resilience?, w: Sourcebook of Family Theory \& Research, ed. V. L. Bengston, A. C. Acock, K. R. Allen, P. Dilworth-Anderson, D. M. Klein, Thousand Oaks-London-New Delhi 2005, s. 112-117.

Barański M., Rodzina od czasów najdawniejszych do końca XVIII wieku, w: Przemiany rodziny polskiej, red. J. Komorowska, Warszawa 1975, s. 23-51.

63 Por. Institute for Family Policies, Report on the Evolution of the Family in Europe, 2009, (12.04.2019); Institute for Family Policies, Report on the Evolution of the Family in Europe, 2018, 12.04.2019).

64 Jan Paweł II, Adhortacja apostolska Familiaris Consortio, 86. 
Beck U., Beck-Gernsheim E., Individualization. Institutionalized Individualism and its Social and Political Consequences, London-Thousand Oaks-New Delhi 2005.

Beck U., Beck-Gernsheim E., Miłość na odległość. Modele życia w epoce globalnej, tłum. M. Sutkowski, Warszawa 2013.

Beck U., Społeczeństwo ryzyka. W drodze do innej nowoczesności, tłum. S. Cieśla, Warszawa 2002.

Bellah R. N., Madsen R., Sullivan W. M., Swidler A., Tipton S. M., Skłonności serca. Indywidualizm i zaangażowanie po amerykańsku, tłum. D. Stasiak, P. Skurowski, Warszawa 2007.

Bielicki T., Struktura rodziny ludzkiej w perspektywie antropologicznej, w: Rodzina - jej funkcje przystosowawcze i ochronne, red. E. Hałoń, Warszawa 1995, s. 9-22.

Bogucka M., Gorsza pteć. Kobieta w dziejach Europy od antyku po wiek XXI, Warszawa 2006.

Boguszewski R., Alternatywne modele życia rodzinnego w ocenie społecznej. Komunikat $z$ badań, Warszawa 2019.

Boguszewski R., Rozwody w osobistych doświadczeniach Polaków, Warszawa 2019.

Boguszewski R., Stosunek Polaków do rozwodu, Warszawa 2019.

Bowbly J., Przywiąanie, tłum. M. Polaszewska-Nicke, Warszawa 2007.

Budzyńska E., Koniec rodziny, jaką znamy?, w: Problemy współczesnej demokracji i moralności, red. J. Kopka, G. Matuszczak, Łódź 2010, s. 281-303.

Budzyńska E., Małe dzieci - mały kłopot? Więziotwórcze funkcje rodziny, w: Więzi międzypokoleniowe $w$ rodzinie i $w$ kulturze, red. W. Świątkiewicz, Katowice 2012, s. 93-135.

Budzyńska E., Międzypokoleniowe więzi w rodzinie. Studium socjologiczne rodzin polskich i słowackich, Katowice 2018.

Delimata M., Dziecko w Polsce średniowiecznej, Poznań 2004.

Dobkowska D., Więzi uczuciowe w rodzinie zrekonstruowanej, w: Materialy do nauczania psychologii, red. L. Wołoszynowi, Warszawa 1984, seria 2, t. 11, s. 363-464.

Dyczewski L., Rodzina. Społeczeństwo. Państwo, Lublin 1994.

Elliot F. R., The Family: Change or Continuity?, London 1986.

Flandrin J.-L., Historia rodziny, tłum. A. Kuryś, Warszawa 1998. 
Fukuyama F., Wielki Wstrząs. Natura ludzka a odbudowa porzadku społecznego, tłum. H. Komorowska, K. Dorosz, Warszawa 2000.

Furstenberg F. F., Cherlin A. J., Divided Families: What Happens to Children When Parents Part, Cambridge 1991.

Gerhardt S., Znaczenie miłości. Jak uczucia wpływaja na rozwój mózgu, tłum. B. Radwan, Kraków 2010.

Gerlich H., Wizerunek niewiasty cnotliwej w górnośląskich przekazach międzygeneracyjnych - od schyłku XIX wieku do połowy XX wieku, w: Kobieta i małżeństwo. Społeczno-kulturowe aspekty seksualności. Wiek XIX i XX, red. A. Żarnowska i A. Szwarc, Warszawa 2004, s. 421-439.

Gierycz M., Europejski spór o człowieka. Studium z antropologii politycznej, Warszawa 2017.

Giza-Poleszczuk A., Przestrzeń społeczna, w: Strategie i system. Polacy w obliczu zmiany społecznej, red. A. Giza-Poleszczuk, M. Marody, A. Rychard, Warszawa 2000, s. 97-166.

Giza-Poleszczuk A., Rodzina a system społeczny. Reprodukcja i kooperacja w perspektywie interdyscyplinarnej, Warszawa 2005.

Giza-Poleszczuk A., Rodzina i system społeczny, w: Wymiary życia społecznego. Polska na przełomie XX i XXI wieku, red. M. Marody, Warszawa 2002, s. 272-301.

Goleman D., Inteligencja emocjonalna, tłum. A. Jankowski, Poznań 1997.

Hałgas I., Scenariusze nie-małżeńskie, „Tygodnik Powszechny” 13 (2000), s. 16.

Hetherington E. M., The Adjustment of Children in Divorced and Remarried Families, w: Sourcebook of Family Theory \& Research, red. V. L. Bengtson, A. C. Acock, K. R. Allen, P. Dilworth-Anderson, Thousand OaksLondon-New Delhi 2005, s. 137-142.

Himmelfarb G., Jeden naród, dwie kultury, tłum. P. Bogucki, Warszawa 2007. Historia życia prywatnego, ed. Ph. Ariès, G. Duby, tłum. K. Arustowicz, M. Rostworowska, red. wyd. pol. A. Łoś, t. 1-5, Wrocław-WarszawaKraków 1999.

Iluk J., Chrześcijańskie małżeństwo i rodzina $w$ rzymskiej starożytności, w: W. Pałubicki, J. Iluk, Małżeństwo i rodzina $w$ dawnym judaizmie i starożytnym chrześcijaństwie, Gdańsk 1995, s. 153-289. 
Iniewicz G., Więzi rodzinne z perspektywy teorii przywiazania, w: Koncepcja przywiązania. Od teorii do praktyki klinicznej, red. B. Jóźwik i G. Iniewicz, Kraków 2008, s. 129-148.

Institute for Family Policies, Report on the Evolution of the Family in Europe, 2009, (12.04.2019).

Institute for Family Policies, Report on the Evolution of the Family in Europe, 2018, 12.04.2019).

Jabłonowska Z., Rodzina w XIX i na początku XX wieku, w: Przemiany rodziny polskiej, red. J. Komorowska, Warszawa 1975, s. 52-71.

Janicka I., Związki kohabitacyjne, w: Psychologia rodziny, red. I, Janicka, H. Liberska, Warszawa 2014, s. 259-284.

Jan Paweł II, Adhortacja apostolska „Familiaris Consortio" Ojca Świętego Jana Pawła II do biskupów, kapłanów i wiernych całego Kościoła katolickiego o zadaniach rodziny chrześcijańskiej w świecie wspótczesnym, w: Adhortacje apostolskie Ojca św. Jana Pawła II, red. J. Poniewierski, Kraków 1997, s. 87-208.

Józefik B., Problematyka rozwodu i rodzin rekonstruowanych - implikacje terapeutyczne, „Państwo i Społeczeństwo” 3 (2005), s. 169-175.

Jundziłł E., Potrzeby psychiczne dzieci i młodzieży. Diagnoza - zaspokojenie, Gdańsk 2000.

Juszczyk-Frelkiewicz K., Kohabitacja w Polsce i na Słowacji. Studium socjologiczne, Katowice 2014.

Kocik L., Wzory matżeństwa i rodziny. Od tradycyjnej jednorodności do wspótczesnych skrajności, Kraków 2002.

Kozdrowicz E., Sytuacja dziecka w rodzinie matki samotnej. Skrypt dla studentów pedagogiki. Warszawa 1989.

Kuby G., Dzieci jako eksperyment seksualny. Obowiazkowa edukacja seksualna w szkołach pewna droga do zniszczenia rodziny i chrześcijaństwa, tłum. M. Czarnik, w: Dyktatura gender, Kraków 2014, s. 29-51.

Kuby G., Globalna rewolucja seksualna. Likwidacja wolności w imię wolności, tłum. D. Jankowska, J. Serafin, Kraków 2013.

Kuby G., Rewolucja genderowa. Nowa ideologia seksualności, tłum. M. Urban CSsR, D. Jankowska, Kraków 2007.

Kwak A., Rodzina i jej przemiany, Warszawa 1994.

Kwak A., Rodzina w dobie przemian. Małżeństwo i kohabitacja, Warszawa 2005. 
Kwak A., Uniwersalność instytucji rodziny i kierunki jej przemian, „Roczniki Socjologii Rodziny" (2002), t. XIV, s. 9-23.

Lewandowska-Walter A., Znaczenie struktury i relacji rodzinnych dla jakości życia dziecka z rodziny zrekonstruowanej, w: Jakość życia rodzinnego. Wybrane zagadnienia, red. T. Rostowska, Łódź 2006, s. 185-197.

Lewis J., The End of Marriage? Individualism and Intimate Relations, Cheltenham, Northampton 2001, Edward Elgar Publishing.

Lis S., Proces socjalizacji dziecka w środowisku pozarodzinnym, Warszawa 1992.

Ludność. Stan i struktura demograficzno-społeczna. Narodowy Spis Powszechny Ludności i Mieszkań, Warszawa 2013.

Majkowski W., Czynniki dezintegracji współczesnej rodziny polskiej. Studium socjologiczne, Kraków 1997.

Marody M., Giza-Poleszczuk A., Przemiany więzi społecznych. Zarys teorii zmiany społecznej, Warszawa 2004.

McCall J., Research on the Psychological Effects of Orphanage Care: A Critical Review, w: Rethinking Orphanages for the 21st Century, ed. R. B. McKenzie, Thousand Oaks, California 1999, s. 127-150, www.parentsinaction.net/english/Kidnaping/The_Psychological_Effects_of_Orphanage_Care.htm (09.03.2012).

Morciniec P., Małżeństwo i rodzina $w$ zderzeniu $z$ gender, w: Familiaris splendor. Piękno życia rodzinnego jako wyzwanie dla społeczeństwa i Kościoła, red. A. Bartoszek, Katowice 2011, Księgarnia św. Jacka, s. 71-88.

Niezgoda M., Młodzież. Kłopotliwa kategoria socjologiczna, „Jagiellońskie Studia Socjologiczne" (2014) nr 1, s. 13-34.

Newman D. M., Grauerholz L., Sociology of Families, Thousand Oaks - London - New Delhi 2002.

Opieka nad dziećmi do 3. roku życia w Polsce i na świecie. Aspekty prawne, ekonomiczne i społeczne. Raport Instytutu Ordo Iuris, red. T. Zych, A. Świerzewska, M. Olek, J. Roszkiewicz, Warszawa 2018.

Paterson C. H., Hidore S. C., The Primary Prevention of Psychosocial Disorders: a Person/Client-centered Perspective, „The Person-Centered Journal" (1997) vol. 4, is. 1, www.sageofasheville.com/primary_prevention. html (09.03.2012).

Peeters M. A., Gender - światowa norma polityczna i kulturowa. Narzędzie rozeznania, tłum. L. Woroniecki, Warszawa 2013. 
Peeters M. A., Globalizacja zachodniej rewolucji kulturowej. Kluczowe pojęcia, mechanizmy działania, tłum. G. Grygiel, Warszawa 2010.

Popenoe D., America's Family Problem, „The Public Perspective”, September/ October (1992), s. 22-24.

Popenoe D., War over the Family, New Brunswick-London 2005.

Popenoe D., Whitehead B. D., Should we live together? What Young Adults Need to Know about Cohabitation before Marriage. A Comprehensive Review of Recent Research, "Smart Marriages", The Coalition for Marriage, Family, and Couples Education, http://www.smartmarriages.com/cohabit.html (02.05.2010).

Rocznik Demograficzny GUS, Warszawa 2019.

Romaniszyn K., Zaufanie w społeczeństwie uRynkowionym, w: Zaufanie społeczne. Teoria - idee - praktyka, red. J. Szymczyk, Warszawa 2016, s. $101-126$.

Rostowski J., Współczesne przemiany rozumienia związku małżeńskiego, w: Psychologia rodziny. Małżeństwo i rodzina wobec współczesnych wyzwań, red. T. Rostowska, Warszawa 2009, s. 15-46.

Roszkowski W., Roztrzaskane lustro. Upadek cywilizacji zachodniej, Kraków 2019.

Saxonberg S., Polityki rodzinne w nowych państwach członkowskich Unii Europejskiej $i$ ich wpływ na role wynikajace $z$ płci oraz prawa jednostki, tłum. M. Kocik, w: Przemiany rodziny $w$ Polsce $i$ we Włoszech $i$ ich implikacje dla polityki rodzinnej, red. E. Leś i S. Bernini, Warszawa 2010, s. 97-114.

Schooyans M., Aborcja a polityka, tłum. K. Deryło, Lublin 1991.

Slany K., Alternatywne formy życia małżeńsko-rodzinnego $w$ ponowoczesnym świecie, Kraków 2002.

Smith W. J., Kultura śmierci. Gdy medycynie wolno szkodzić, tłum. M. Reda, Kraków 2019.

Sołoma L., Socjologia, Olsztyn 1998.

Stankowska M., Długoterminowa konsekwencje rozwodu. Problemy dorosłych dzieci z rodzin rozwiedzionych, w: Wielość spojrzeń na matżeństwo i rodzine, red. A. Kwak, M. Bieńko, Warszawa 2012, s. 147-176.

Strategia zniszczenia i konfliktu, Rozmowa z prof. Piotrem Jaroszyńskim, kierownikiem Katedry Filozofii Kultury i Sztuki KUL, „Nasz Dziennik” (2019) nr 173, s. 2. 
Sunderland M., Mądrzy rodzice, tłum. A. Wyszogrodzka-Gaik, Warszawa 2008.

Sytuacja demograficzna Polski do 2018 roku. Tworzenie i rozpad rodzin, Warszawa 2019.

Szwarc A., Rygorystyczne normy i swobodne obyczaje. Małżeństwo i związki pozamałżenskie $w$ opiniach ziemiańsko-arystokratycznej elity $w$ połowie XIX wieku, w: Kobieta i małżeństwo. Społeczno-kulturowe aspekty seksualności. Wiek XIX i XX, red. A. Żarnowska i A. Szwarc, Warszawa 2004, s. 89-101.

Turner J. H., Socjologia. Koncepcje i ich zastosowanie, tłum. E. Różalska, Poznań 1998.

Tyszka Z., Struktura i funkcje rodziny oraz świadomość rodzinna, w: Podstawowe pojęcia i zagadnienia socjologii rodziny, red. Z. Tyszka, A. Wachowiak, Poznań 1997, s. 43-60.

Vitz P. C., Family Decline: The Findings of Social Science, 1999, www.catholiceducation.org/en/controversy/marriage/family-decline-the-findings-of-social-science.html (04.03.2014).

Wallerstein J. S., Blakeslee S., Rozwód. A co z dziećmi?, tłum. C. E. Urbański, Poznań 2003.

Zeanath Ch. H., Smyke A. T., Koga S. F., Carlson E., Attachement in Institutionalized and Community Children in Romania, „Child Development” 5 (2005), vol. 76, s. 1015-1028.

Ziemska M., Wpływ przemian funkcji rodziny na socjalizację dzieci, w: Rodzina i dziecko, red. M. Ziemska, Warszawa 1979, s. 227-254.

Żołądź-Strzelczyk D., Dziecko w dawnej Polsce, Poznań 2002.

Żyromski M., Rodzina jako podstawowa mikrostruktura społeczna w średniowiecznej Polsce, „Roczniki Socjologii Rodziny” (1998), t. 10, s. 145-157. 